\title{
Basque correlatives and their kin in the history of Northern Basque
}

\author{
Georges Rebuschi
}

Relative correlatives in Northern Basque are more restricted than in some other languages. First, they are stylistically marked as highly rhetorical, second, they only impart a generic reading, and thus do not function like ordinary restrictive correlatives as in e.g. Hindi. This paper, which is mainly descriptive, will be concerned with the syntactic differences that help distinguish between correlative relatives and other non-root clauses with and without a $w h$-item: embedded questions, appositive relatives, and indefinite free relatives, semifree relatives, conditional and unconditional protases. Hitherto unnoticed examples are provided which show how the close semantic connection between the various types of subordinated clauses examined here have triggered some interesting overlaps in the history of the language.

Key words: Basque, embedded questions, free relatives, semi-free relatives, unconditional clauses

\section{Introduction}

\subsection{The Basque language}

Basque is a language isolate, spoken on both sides of the French-Spanish border on the Atlantic coast. Three basic groups of dialects are recognized today (Zuazo 1998): Western (or Biscayan, bizkaiera), Central (or Guipuzcoan, gipuzkera), and Eastern, a term which subsumes most of the varieties spoken in Spanish Navarre (Nafarroa), and those spoken in the French Basque Country - the "Northern dialects". Sub-varieties are countless, but it is customary to distinguish, among the varieties of Northern Basque, between, from the Atlantic coast eastwards: Labourdin Basque (lapurtera), Low Navarrese (behe-nafarrera) and Souletin Basque (zuberera). The first book ever printed in Basque, Etchepare (1545), was written in Low Navarrese. The two other monuments of Basque literature were also written in Northern Basque: Leiçarraga’s (1571) translation of the New Testament aimed at a cross-dialectal language, but its basis was fundamentally 
Labourdin, and the Basque classical text par excellence, Axular's (1643) Gero, was written in the same dialect. Until the end of the 19th century, Basque literature was mainly religious, and mostly consisted of translations. As we shall see, this can turn into an advantage, since the translations provide us with many paraphrases of what are basically the same source texts (mainly the four Gospels, and Thomas a Kempis' Imitation of Christ). Independently of the relative wealth and ancientness of Northern Basque in general, this paper will concentrate on this variety of Basque because in this variety complex correlative sentences (as they will be defined presently) have been attested throughout its history, and are still alive today (although they are stylistically marked as literary or rhetorical).

\subsection{Why this study?}

Pretheoretically, correlative structures are pervasive in natural languages. The word "correlative" can refer to (pairs of) words, as in: "Both, but not each, is also used as a correlative with and in linked predications" (Quirk et al. 1972: 364). The same authors also use "subordinating correlatives" (p. 528) and "correlative subordinators" (p. 728 ) indiscriminately to describe pairs like 'if... then, (al)though... yet/nevertheless, as... so [...]'. Greenbaum (1969: 120) refers to "correlative constructions" when discussing the impossible ellipsis of the subject in sentences like Although they did not like the music, yet ${ }^{\star}$ (they) applauded vigorously, and he uses the expression "correlative structure" to refer to an example like It's not that he's young; it's just that he's inexperienced (id.: 120). ${ }^{1}$

Many recent studies of correlative constructions have been devoted to a specific subclass of complex correlative sentences, henceforth CCSs, which are well-kown in the ancient Indo-European languages (Latin, Greek, Sanskrit, Hittite) - see e.g. Haudry (1973) for an overwiew - and are still attested in modern Indo-European languages: the Slavic languages (Izvorski 1996, Boškovič 1997, and Citko, this volume) or Hindi (Srivastav 1991, Dayal 1996, Bhatt 2003), but also in languages that belong to quite distinct phyla such as Bambara (Zribi-Hertz \& Hanne 1995), Burushaski (Tiffou \& Patry 1995), Hungarian (Lipták 2000, 2005), and Tibetan (Cable 2005, this volume). This subclass of CCSs is characterised by a left-peripheral relative clause or protasis $>$ linked to a (possibly phonetically unrealised) pronominal correlate in the main clause that follows it, also known as the apodosis. In the examples below, the paired items are in italics.

(1) a. BAMBARA

(Zribi-Hertz \& Hanne 1995)

Musa ye uru min san, $\mathrm{n}$ ye $o \mathrm{ye}^{2}$

Musa PRF knife REL buy 1SG PRF it see

'I saw the knife that Musa bought.' 
b. BURUSHASKI

(Tiffou \& Patry 1995)

amenmoiNga baris écam (ka) mo gusmoina

which.сом words I.will.do and the woman.com

are sail ayét.

with walk don't

'Dont (take a) walk with the woman with whom I'll speak.'

It has become customary in contemporary formal linguistics to use the phrase "correlative clauses" to refer not to the apodosis which contains the pronominal correlate, as is standard usage in the literature devoted to the ancient languages, but rather to the protasis $>$ itself. I will therefore altogether ignore that expression in this paper, and use the expression "correlative protasis" (or CorPs) to refer to the clausal material in the left periphery of the main clause.

Basque CCSs are of special interest for at least three reasons. ${ }^{3} \mathrm{~A}$ first reason is that it is possible to observe some facts concerning the evolution of CCSs and of related constructions in the period of four and a half centuries, reflected in the texts to be inspected. The second reason is typological. Whereas in all the languages mentioned above the CorP can function as a restrictor over a domain given by the correlate in the apodosis (e.g. 'the woman' in (1b)), in Basque the correlate does not define anything at all. Lexically headed DPs normally do not appear in the apodosis, instead we have a pronominal correlate in the form of a demonstrative. This demonstrative furthermore does not "choose" between human beings or inanimate entities: all the restrictions are provided by the CorP itself. Thus, if the (semantic) predicates of the protasis $>$ and apodosis are compatible with both human beings and things, as in (2), it is only the wh-element in the protasis that reveals the nature of the entities referred to.

(2) Nor/zer ere maite bait-dut, (eta) hura begira-tuko dut. who what ever love bait-〈A3E1〉 and DEM preserve-PROS 〈A3E1〉 Lit., 'Whoever/whatever I like/love, and them/that I will look after.'

It follows that when the wh-phrase is not discourse-linked, (Northern) Basque CorPs are free relatives (FRs) which are generically or universally understood: they cannot denote maximal individuals, because they are concerned with open, rather than closed, sets. A final reason for the study of Basque CCSs is that, next to correlatives, all the dialects have a very distinct way of building what can generally also translate into free relatives: by using "semi-free relatives" (SFRs) to be described in 2.3.

To summarise, Basque CCSs actually appear at the intersection of three families of constructions that resemble each other either in their syntax or in their semantics: (i) semi-free relatives, (ii) non-independent wh-clauses of various types, and (iii) conditional clauses which contain either an existential pronoun like 'someone' or 'something', or a negative polarity item like 'anybody' or 'anything. The purpose of this paper, next to providing a general description of Basque CCSs, is to review these three construction types and to show how they differ from CCSs. 


\subsection{Organisation of the paper}

This paper is basically descriptive and is organized as follows. The general background data will be provided in Section 2, together with a description of common restrictive and appositive relatives, and of the semi-free relatives alluded to above. Section 3 will turn to the essential properties of CorPs and complex correlative sentences and will compare CorPs and semi-free relatives. Section 4 will be devoted to a systematic comparison of CorPs with other non-independent wh-clauses. Section 5 will examine "generic" conditional sentences, and observe some intriguing converging properties that they share with CCSs. Finally, Section 6 will briefly recapitulate some of the results obtained in the preceding sections.

\section{Background data}

This section will introduce the reader to some general properties of Basque. The following topics will be handled: case-marking and basic word- and phrase-order (2.1); the various ways of marking distinct types of embedded clauses (2.2); the most common way of building relative clauses (2.3); syntactically appositive relatives (2.4); and some properties of appositive relatives and SFRs (2.5).

\subsection{Some typological properties of (standard) Basque}

Basque has an absolutive/ergative case system and the basic structure of the simple sentence is generally considered to be SOV, as shown in (3a-b). Note that case-endings appear on the right edge of the NP/DP, not on every element the NP/DP contains.

(3) a. [Gizon gaztea]-k [liburu zaharra] irakurr-i du.

man young.sG-E book old.sG read-PRF〈A3E3〉

'The young man has read the/an old book'.

b. [Gizon zaharra] etorr-i da.

man old.sG come-PRF〈A3〉

'The old man has come.'

The finite verb form (FVF), which is either an auxiliary or a handful of directly inflectable lexical verbs, is cross-referenced pluripersonally if the verb has more than one arguments. In the present tense, the absolutive morpheme is a prefix, and the dative and ergative agreement morphemes are suffixes. The choice of the auxiliary depends on the transitivity of the verb (and its possible dative extension), not on the choice of the participial suffix, as shown in (4). Note also that the synthetic conjugation, when it is possible, as in (4c), is semantically progressive, whereas its periphrastic or compound counterpart is iterative or habitual. 
(4) a. Gizona-k liburua irakurr-i/tzen/iko du. man.SG-E book.sG read-PRF/IMPF/PROS〈A3E3〉 'The man has read / reads / will read a/the book.'

b. Haurra etorr-i/tzen/iko da child.sG come-PRF/IMPF/PROS〈A3〉 'The child has come / comes / will come.'

c. Haurra (ba-)dator.

child.sG PRTC-come〈3A〉

'The child is coming.'

Owing to this rich verbal morphology, Basque is a generalised pro-drop language: subjects, but also direct and indirect objects need not be expressed by phonetically realised pronouns.

The basic sov word order in Basque can be affected by various processes, in particular those that raise various items towards the functional projections in the left periphery of the sentence. In fact, sov as such typically occurs in totally rhematic sentences, contributing the information required by a question like Zer gertatu/gertatzen $d a$ ? 'What's happened/happening?'. Whereas as soon as either a topic or a focussed item must appear, Basque looks much more like a "discourse configurational language", to borrow É. Kiss's (1995) typological characterisation. Further, interrogative whphrases must, at least in today's Basque ${ }^{4}$, be left-adjacent to the verb complex (the FVF if the lexical verb is inflected or the sequence participle + auxiliary otherwise), as shown in $(5 \mathrm{a}-\mathrm{c})$. Focussed phrases and replies to wh-questions must occupy the same linear position as shown in $(6 \mathrm{a}-\mathrm{c})$, where the small caps indicate prosodic salience.

(5) a. Liburu hau, nor-k irakurr-i du?

book this who-E read-PRF 〈A3E3〉

'This book, who has read (it)?'

b. Nor-k irakurr-i du liburu hau? who-E read-PRF〈A3E3〉 book this

'Who has read this book?'

c. ${ }^{\star}$ Nor-k liburu hau irakurr-i du? who-E book this read-PRF 〈A3E3〉

(6) a. Patxi-k irakurr-i du liburu hori. Patxi-E read-PRF〈A3E3〉 book that '(It's) PAtxi (who) has read that book.'

b. Liburu hori, Patxi-k irakurr-i du. book that Patxi-E read-PRF $\triangle \mathrm{A} 3 \mathrm{E} 3$, 'That book, (it is) Patxi (who) has read (it).'

c. ${ }^{\star}$ Patxi-k liburu hori irakurr-i du.

Patxi-E book that read-PRF $\langle$ A 3E3 
(5c) and (6c) are ungrammatical in today's Basque, and were highly marked in the older language, because the wh-word and the focussed element - the latter either indicating contrast or providing (new) information - do not immediately precede the verb complex.

\subsection{Embedded clauses}

The marking of embedded clauses is done by four distinct morphemes that function as complementizer heads and can be affixed or cliticised to the FVF. The first two of these morphemes are clearly suffixes. One, -(e)la, basically marks completive clauses, as in (7):

(7) Patxi-k uste du [haurra-k liburua irakurr-iko du-ela].

Patxi-E belief has child.sG-E book.sG read-PROs 〈A3E3〉-COMP

'Patxi thinks that the child will read the book.'

The other suffix is -(e) $n$; it occurs in indirect questions (8a), in some exclamative sentences ( $8 \mathrm{~b}$ ), and, as we shall see in 2.3 , in relative clauses which contain an abstract, or phonetically empty, relative operator.

(8) a. Ez dakit [nor etorr-i d-en].

$[$ den $=d a+-e n]$

NEG I-know who come-PRF $\langle\mathrm{A} 3>-e n$

'I don't know who has come.'

b. Zenbat jende etorr-i d-en!

how.many people come-PRF 〈A3〉-en

'How many people have come!'

The other items are $b a$ - 'if', which can be found with indicative mood, as in (9a), or other moods (potential, irrealis...), and bait-, which serves several purposes, among which that of marking the FVF in relative clauses that display a wh-word or phrase, cf. (9b). ${ }^{5}$ In (9c), we illustrate successively the relative-marking function of bait- on the one hand, and its function of marking that the clause is governed by specific items (hain... non'such/so much... that').

(9) a. Adi-tzen ba-nau, uler-tuko du.

hear-IMPF if-〈A1E3〉 understand-PROs 〈A 3E3〉

'If s/he hears me, s/he will understand.'

b. Ba-dire ${ }^{6} \ldots$ kasu batzu, zeinetan barur egin

PRTC-are case some which.PL.LOC fast make

behar bai-ta.

(Duhalde 1809: 5)

must/necessary bait-〈A3〉

'There are some cases in which one must fast.' 
c. Hauk dira Eskuara-ren hitzak, [...] zein-eta-n

these are Basque-GEN words.PL which-PL-LOC

edirei-ten bai-tira hain [...] signifikanza misteriotsuak,

find-IMPF bait-〈A6〉 so meaning mysterious.PL

non bai-tirurite Philosophoe-n sentenziak.

that bait-they.look.like philosopher.PL-GEN maxim.PL

(Etcheverry of Sare, [1712] 1907: 45)

'These are Basque words, in which such mysterious meanings are found that they resemble the maxims of philosophers [...]'

\section{3 -(E)n relatives and semi-free relatives}

Consider the DPs in $(10 b, c)$. The bracketed sequences correspond to sentence (3a), repeated without the adjectives (for better readibility) as (10a), with a gap in object or subject position respectively (marked by $e$ ). They are restrictive relatives which modify the nouns liburu and gizon (or, more technically, restrict the domain introduced by the translation of the nouns): ${ }^{7}$

(10) a. Gizon-a-k liburu-a irakurr-i du.

man-SG-E book-SG read-PRF〈A3E3〉

'The man has read the/a book.'

b. [CP gizon-a-k $e$ irakurr-i du-en] liburu-a man-SG-E read-PRF〈A3E3〉-en book-SG 'the book [that the man has read -]'

c. [[e liburu-a irakurr-i du-en] gizon-a] zuhurr-a da. book-SG read-PRF $\langle\mathrm{A} 3 \mathrm{E}\rangle$-en man-SG wise-SG he-is '[The man [that - has read the book]] is wise.'

As could be expected, the case of the DP that contains the restrictive relative is linked to the function of that DP in the higher clause. Thus, in the case of (10c), in spite of the fact that the pivot, or relativised position in the embedded clause, corresponds to that of the subject of a transitive verb, the whole DP is in the absolutive or zero case (there is no case suffix on gizon- $a$ ). On the oher hand, in (11) below, the relativised position is that of the subject of an unaccusative verb (cf. the aux. $d a=\mathrm{A} 3$, lit. 'he is'), a DP that would be in the absolutive case if it were phonetically realised. The whole DP on the other hand is in the ergative case, because it is the subject of the transitive verb irakurri $d u$ 'he has read it'.

(11) [[ e Etorr.i d-en] gizon-a]-k liburu-a irakurr-i du. come.PRF 〈A3〉-en man-SG-E book-SG read-PRF 〈A 3E3 > 'The man that has come has read the book.' 
The head noun in these kind of relatives can also be elided., as in (12), where the second occurrence of gizon 'man' is missing is represented by means of a dash in the second relative clause.

$$
\begin{aligned}
& \text { [[[e Liburu-a irakur-tzen du-en] gizon]-a] eta [[[e } \\
& \text { book-sG read-IMPF 〈A3E3〉-en man-sG and } \\
& \text { astekari-a irakur-tzen du-en]-]-a] gazte.ak }{ }^{8} \text { dira. } \\
& \text { weekly-SG read-IMPF 〈A3E3〉-en- } \emptyset \text {-sG young.PL they.are } \\
& \text { 'The man that reads the book and the one that reads the weekly are young.' } \\
& \text { Lit., '.... and [the - [that [- reads the weekly]]]...' }
\end{aligned}
$$

In another context, a DP like the second conjunct in (12) could also be interpreted as a free relative, i.e. a relative that does not modify any "understood" or contextually recoverable NP:

(13) [Irakur-tzen du-en ---a] zuhurr-a da. read-IMPF 〈A $3 \mathrm{E} 3\rangle-e n-\varnothing-\mathrm{SG}$ wise-sG is

'He who reads is wise.'

It must be underlined that if the bracketed sequence in (13) is interpreted as referring to human beings, this is merely an effect of the lexical choice of the verb and our knowledge of the world. With a verb like erori 'fall (down)', for instance, the expression is totally ambiguous between a reading referring to human entities and a reading referring to non-human ones, whether it is in the singular, or in the plural:
a. eror-i d-en---a
fall-PRF〈A3〉-en-Ø-sG
which has fallen'
b. eror-i dir-en---ak
fall-PRF $\langle A 6\rangle-e n-\varnothing-P L$
'those [ \pm human] that have fallen'

I label these kind of headless relative clauses "semi-free relatives", SFRs for short, "semi" because they are dominated by the functional projections characteristic of nominal expressions: a Number Phrase and a DP (see Rebuschi 2000 for arguments). For the syntactic representation of these relatives, in particular for the representation of the functional layers above the CP, I will adopt the analysis of Artiagoitia (2002) for Basque DPs. According to this there are two options concerning the insertion, or "external merge", of the article $-a(k)$ : one is directly under $\mathrm{D}^{\circ}$, if this node carries a [+definite] feature, the other is under $\mathrm{Num}^{\circ}$ if $\mathrm{D}^{\circ}$ is [-definite]. In the latter case, the number suffix will later raise to $\mathrm{D}^{\circ}$ so as to carry a possible case suffix. Transferring this analysis to SFRs, the result is (15a) or (15b). Op here represents the abstract relative operator in the specifier of the relative $\mathrm{CP}$. 
(15)

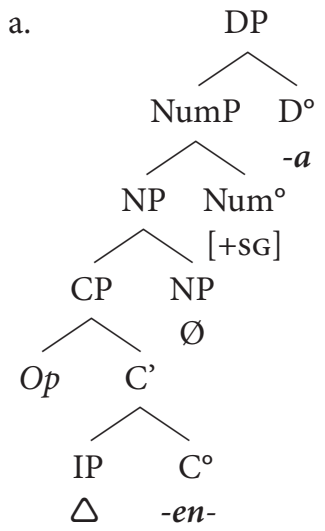

b.

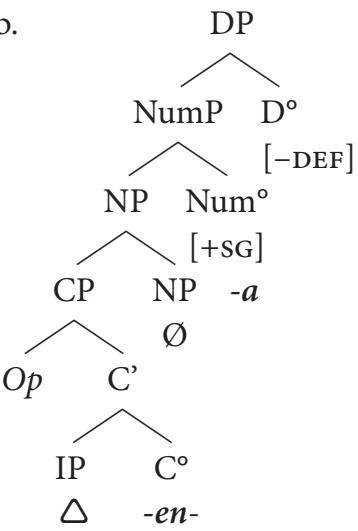

Elliptical DPs stricto sensu, like the one in (12) - i.e. those that contain an empty anaphoric NP - must of course have a structure like (15b). As for SFRs, I tentatively argued elsewhere (Rebuschi 2001) that a simpler structure, in which the CP would be the direct complement of the Num(ber) head, should suffice. Yet, this is not obviously true. For instance, an SFR in the locative case has three readings:

(16) irakur-tzen du-en- - -e-an read-IMPF 〈A3E3)-en-(Ø-)SG-LOC

(i) anaphoric interpretation: 'in the (one) that $\mathrm{s} / \mathrm{he}$ reads'

(ii) generic FR interpretation over objects: 'in what s/he reads'

(iii) generic FR interpretation over time points or intervals: 'when s/he reads'

One may therefore infer that an empty NP is always present, which minimally possesses either a [+entity] feature, as in (i) and (ii), or a [+time] feature, as in (iii). 


\subsection{Appositive relatives}

A different kind of relative clause, which Basque has always displayed ${ }^{9}$ is introduced by the wh-phrase zein- 'which'. This kind of relative clause uses the bait-complementiser illustrated in $(9 b, c)$ above. Already in the 16th century, the wh-word could be left unpronounced (a stylistically preferred variant today, but a much rarer option in the past). Whether their wh- element is realised or not, bait- relative clauses always follow the "modified" nominal expression: they are either simply adjoined to a case-marked DP, like gure eskuara $(k)$ in (17a), or extraposed to the right of the clause that contains the relevant DP, as in (17b).

a. Lege hau segi-tu du gure Eskuara-k, law this follow-PRF $\langle\mathrm{A} 3 \mathrm{E} 3\rangle$ our Basque-language-E zein- $a$ hanbat mende-z mantena-tu eta which-SG so-many century-INST maintain-PRF and mantena-tzen bai-ta. (Etcheverry of Sare [1712] 1907: 23) maintain-IMPF bait-〈A3>

'Our Basque language, which has defended itself for so many centuries, has conformed to this law.

b. Eneko, eta Semeno Nafarroa-ko Errege iza-n ziren, Eneko and Semeno Navarre-GEN king be-PRF〈A1[PST]〉 $z e i n-e-n$ izene-k aski klarki aditzera zein-PL-GEN name.PL-E enough clearly to.understand emai-ten bai-tarokute Eskualdun izenak dire-la. give-IMPF bait-〈A3D3E6〉 Basque name.PL they.are-COMP 'Eneko and Semeno were kings of Navarre, whose names let sufficiently clearly understand that they are Basque names.' (id.: 34)

Owing to the "purification" of the language advocated at the end of the 19th century, however, this type of relatives tends to be rejected as a Romance calque today, especially when used with an intended restrictive meaning. In the Central and Western dialects, the complementiser $-(e) n$ (or its variant $-(a) n)$, mentioned in 2.3 above, was, and still is, used in wh- relative clauses.

Appositive relatives can be adjoined to a demonstrative pronoun (with the same interpretation as elliptical -en.a(.k) expressions in some contexts). In the Labourdin dialect, from the 16th century to the end of the 19th, a special pronoun, haina, lit. 'the such' was used instead of a demonstrative when the intended meaning was that of a "real", non-anaphoric free relative, cf. (18b). This paraphrases the SFR in (18a) (more on haina in 3.1). 
(18) Mt 11,27 - LV: 'Et nemo novit Filium nisi Pater, neque Patrem quis novit, nisi Filius et cui voluerit Filius revelare.' / KJV 'And no man knoweth the Son, but the Father; neither knoweth any man the Father, save the Son, and he to whomsoever the Son will reveal him.'

a. Eta nihor-k ez du ezagu-tzen Semea and nobody-E NEG 〈A3E3〉 know-IMPF Son.sG Aita-k baizen, eta nihor-k ez du ezagu-tzen Father-E but and nobody-E NEG 〈A3E3〉 know-IMPF Aita [[Semea-k baizen] eta [[Semea-k Father-sg Son.sG-E but and Son.sG-E erakutsi iza-n nahi dio-en-a-k] baizen]]. show AUX-PRF want 〈A3D3E3〉-en-SG-E but

(Haraneder 1740)

b. eta haina-k zein-a-ri Seme-a-k nahi iza-n and such.SG-E zein-SG-D son-SG-E want AUX-PRF bai-tio ezagut-araz-i. (Duvoisin 1859-65) bait-〈A3D3E3〉 know-FACT-PRF

Lit., '[...] and the-such to whom the Son has wanted to reveal (him).'

As (19) shows, the appositive relative could also be extraposed in such cases.

(19) Imit. 1,25,3 - Thomas's original Latin text: Illi maxime præ aliis in virtutibus proficiunt, qui ea quæ sibi magis gravia et contraria sunt vincere nituntur.

Benham's (1905) translation: 'Nevertheless they advance above all others in virtue who strive manfully to conquer those things which are most grievous and contrary to them.'

Bertzenaz hainak gehienean berthutea-n aitzina-tzen dire, otherwise such.PL mostly virtue.SG-LOC advance-IMPF 〈A6〉 zein-ak animo gehiago-rekin ensaia-tzen bai-tire who/which-PL courage more-COM try-IMPF bait-〈A6 traba-rik handi-en-e-n [...] garaitzerat (Chourio 1720) obstacle-PRTC big-most-PL-GEN to.surmount

\subsection{Further properties of appositive relatives and SFRs}

SFRs can be right-adjoined to a DP and can be coordinated with appositive relatives introduced by a wh-phrase (zoin- in (20a) is a dialectal variant of zein-):

(20) a. Mundu hun-en konprenitzeko, behar da izaite world this-GEN to.understand necessary is being bat, bethi-tik $d$-en- $a$, nihor-k egi-n ez one always-ABL is-en-SG nobody-E make-PRF NEG 
du-en-a, eta zoin-a-k egin bai-titu

$\langle\mathrm{A} 3 \mathrm{E} 3\rangle-\mathrm{en}-\varnothing$-SG and which-SG-E made bait-〈A6E3〉

dire-n guzi-ak.

(Lapeyre [1891] 1982: §36)

are-en all-PL

'In order to understand this world, we need a being that has always been, that nobody has made, and that has made everything that is.'

b. Asko ezagu-tu dituzket ni baino gazte-ago-ak, ni-k many know-PRF 〈A6E1〉 1sG than young-more-PL I-E bezain luzeki bizitzeko iduri ederr-a as-much long to.live appearance beautiful-sG zu-te-n-ak, eta zein-ak ez-pai-tire orai they-had-en- $\varnothing$-PL and zein-PL NEG-bait-are now mundu-a-n.

(Duhalde 1809: 121) world-SG-LOC

'I have known many people younger than I who looked as if they were to live as long as myself, and who are no longer in this world.'

Such examples show that the interpretation of both types of clauses must sometimes be restrictive rather than appositive. However, I shall stick to the label "appositive relatives" to reflect their syntactic structure, i.e. the fact that they are undeniably adjoined to a case-marked DP, rather than c-commanded by $\mathrm{D}^{\circ}$.

Interestingly, fully case-marked SFRs can be conjoined and still denote a single (possibly maximal) individual, as shown by (21) where, baina ( $n$ ) 'but', just as the source text(s), ${ }^{10}$ blocks a different reading.

(21) Mt 10,28 - LV: 'Et nolite timere eos, qui occidunt corpus, animam autem non possunt occidere; sed potius eum timete, qui potest et animam et corpus perdere in gehenna.'

KJV: 'And fear not them which kill the body, but are not able to kill the soul: but rather fear him which is able to destroy both soul and body in hell.'

a. Eta et-zaretela beldur gorputz-a hil-tzen

and NEG-be[IMP5'] afraid body-SG kill-IMPF

dute-n-en, eta arima ezin hil 〈A3E3〉-en-PL-GEN and soul.sG NEG $\sqrt{\text { kill }}$

dezakete-n-e-n: baina aitzitik zareten

〈A3E6[POT]>-en-PL-GEN but on.the.contrary be[IMP5']

beldur arima eta gorputza gehena-n gal

afraid soul.sG and body.sG hell-Loc $\sqrt{\text { ruin/lose }}$

ahal ditzake-n-a-ren.

(Leiçarraga 1571)

can 〈A6E3[РОT]〉-en-SG-GEN 
b. Ez duzuela beldurr-ik gorphutz-a hil-tzen NEG have[IMP] fear-PART body.sG kill-IMPF dute-n-e-z eta arima ezin hil $\langle\mathrm{A} 3 \mathrm{E} 6\rangle-e n-\mathrm{PL}-\mathrm{INST}$ and soul.sG cannot kill dezakete-n-e-z: bainan zarete-n beldur 〈A3E6[POT]〉-en-PL-INST but be[IMP] afraid hobeki bai arima eta bai gorputza ifernua-n better PRTC soul.sG and PRTC body.sG hell.sG-LOC gal-araz detzake-n-a-z.

(Haraneder 1740) $\sqrt{\text { lose-FACT } 〈 \mathrm{~A} 6 \mathrm{E} 3[\text { РОт] }>-e n-S G-I N S T}$

c. Ez izan beldur-rik [[gorputza hil-tzen dute-n-e-i]

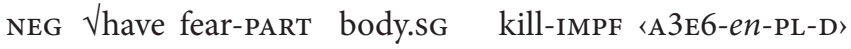
baina [arima ezin hil dezakete-n-e-i]]. ("EHEG" 1980) $)^{11}$ but soul.sG cannot $\sqrt{\mathrm{kill}}$ 〈A3E6[pot]〉-en-PL-D〉

(Note that neither qui in Latin, nor them which (=those who) in the King James version are repeated in the second conjunct.)

Returning to the discussion of the structural properties in (15), we can now say that SFRs are contained in a DP whose head is [ \pm definite]. If it is [-definite], the interpretation will yield a property (an option that is compositionally compatible with SFRs that are in fact restrictive). If the head is [+definite], it will provide either a maximal individual, if the given set is closed, or a generalised quantifier (with universal or generic force), if the set is open.

When they are not interpreted as properties, SFRs can appear in argumental position, cf. (22), be focussed, cf. (23), or left-dislocated, cf. (24).
a. Erakaslea-k [huts egi-nen du-en-a] zigor-tuko du. teacher.SG-E mistake make-PROs〈A3E3〉-(e)n-SG punish-PROs〈A3E3〉 'The teacher will punish [the one who will make a mistake].'
b. [Huts egi-nen du-en-a] zigortua iza-nen da. mistake make-PROS〈A3E3〉-(e)n-SG punished.sG be-PROs〈A3〉 'The one who will make a mistake shall be punished.'

(23) [Huts egin-en du-en-a] izan-en da zigortua. mistake make-PROs 〈A3E3〉-en-SG be-PROs 〈A3〉 punished.sG '(It's) The one who will make a mistake (that) shall be punished.'

(24) [Huts eginen duena], hura zigortua izanen da. DEM ...

Lit., 'The one who will make a mistake, that (one) shall be punished.' Zein (a) + bait- appositive clauses on the other hand cannot appear in such positions as these. Interestingly, they also very rarely appear under the scope of an existential predicate 
like ba-da 'there is' (or ba-dire 'there are' as in (9b)). When they do, they are very strongly felt as Latin calques. SFRs, on the other hand, are perfect in such contexts. ${ }^{12}$

\section{Basque correlative protases and complex correlative sentences}

\subsection{Introduction: "nor/zer... bait-" free relatives}

In addition to the relatives described above, there exists yet another type of free relative, which is to be found in the correlative protasis> proper (CorP) of complex correlative sentences (CCSs), already illustrated in (2) above. The following excerpts from the NT illustrate CorPs, and CCSs as a whole, across four and a half centuries of Northern Basque texts. These examples clearly indicate, in comparison with the source texts (the Latin Vulgate for Haraneder and Duvoisin), that the CCSs have a universal flavour to them.

(25) Mt 12,50 - LV: 'Quicumque enim fecerit voluntatem Patris mei, qui in caelis est, ipse meus frater et soror et mater est' / KJV: 'For whosoever shall do the will of my Father which is in heaven, the same is my brother, and sister, and mother.'

Ezen nor-k ere egi-nen bai-tu ene Aita

for who-E ever do-PROSP bait-〈A3E3〉 my father

zeru-e-tan d-en-a-ren ${ }^{13}$ borondatea, hura da ene

heaven-PL-LOC is-en-SG-GEN will.sG DEM is my

anaye, eta arreba, eta ama.

brother and sister and mother

(Leiçarraga 1571)

(26) Mt 10,22 - LV: 'Qui autem perseveraverit in finem, hic salvus erit.'

KJV: ' . . but he that endureth to the end shall be saved.'

Bainan nor-k ere irau-nen bai-du akhabantza-raino,

but who-E ever last-PROS bait-〈A3E3 $>^{14}$ end-until

eta hura iza-nen da salbatua.

(Haraneder 1740)

and DEM be-PROSP 〈A3〉 saved.sG

(27) 1 Jn 2,10-11 - LV 'Qui diligit fratrem suum, in lumine manet... qui autem odit fratrem suum, in tenebris est...' / KJV 'He that loveth his brother abideth in the light... But he that hateth his brother is in darkness.'

Nor-k ere maite baitu bere anaia, haina

who-E ever love bait-〈A3E3〉 his brother such.SG

argia-n dago, [...] bainan nor-k ere higuin baitu

light.SG-LOC is but who-E ever hate bait-〈A3-E3〉

bere anaia, ilhunbe-tan da haina.

his brother darkness-LOC is such.sG

(Duvoisin 1859-65) 
Needless to say, these structures (which do not translate a Latin correlative in (25)), are not only attested in translations, but also in original texts. (28a) is from the first book ever printed in Basque, and (28b) from the late 18th century.

(28) a. Ni-k nor-gatik pena bait-ut, hark ene eztu

I-E who-for pain.sG bait-I.have DEM-E of.me NEG.has

axol-ik.

(Etchepare 1545: VII, 20)

concern-PART

'He/she/the one because of/for whom I suffer does not worry for me.'

b. Norat ere arbola eror-tzen bai-da, han bethi

whither ever tree.sG fall-IMPF bait-〈Al〉 there always

ego-nen da; zer ere estatu-tan hil-en

stay-PROs〈A3〉 what ever state-LOC die-PROS

bai-zare, hala eternitate guzia-n iza-nen zare

bait-〈A5〉 thus eternity all.sG-LOC be-PROSP 〈A5〉

'Wherever a tree falls, it will stay there; in whatever state you will die, you will remain in the same state in all eternity.'

(Baratciart 1787: 156)

The protasis $>$ of each of the sentences in (25)-(28) contains an interrogative wh-word, nor who' and zer 'what'. As has been pointed out above in 2.4, and as the next section will show, these wh-phrases cannot be used in appositive relatives. The apodosis of CCSs contains a pronominal correlate, either a demonstrative, cf. hura 'that (one)' or its manner counterpart hala 'thus' or haina, the special item alluded to above. Haina had most of the properties of what could be called a lexicalisation of an E-Type pronoun: it could not be used deictically, could not anaphorically refer to an entity, and could not be c-commanded by (even) a non-referential antecedent in an argumental position (see Rebuschi 1998 for details).

Yet another noteworthy feature of CCSs, illustrated in (26), is that the protasis> and the apodosis can be "linked" by what is otherwise an ordinary conjunction, eta 'and'. In fact, eta in this context is very frequent with some authors, and fairly rare with others. Most examples of CCSs given by Oyharçabal (2003: 818-821) contain eta. When eta is present, the correlative demonstrative is often found focussed in a position right-adjacent to eta. Eta may cliticize to the correlative protasis, an independently attested property of eta as a real conjunction, cf. Rotaetxe Amusategi (2004).

\subsection{Are there "nor-/zer-... bait-" relatives in argumental position?}

Some nor-/zer- free relatives apparently appear in the right periphery of a sentence. For illustration, consider (29a), which roughly repeats the contents of Mt 11,27 in (18). In this example, a wh-relative seems to be coordinated with a DP, Semeak 'the Son-E'. But such constructions should not be dealt with independently of the paraphrase provided by (29b), which is much preferred stylistically today. 
(29) Lk 10,22 - LV: '[...] nemo scit [...] qui sit Pater, nisi [[Filius] et [cui voluerit Filius revelare]].' / KJV: '[...] no man knoweth who [...] the Father ${ }_{i}$ is, [[but the $\mathrm{Son}_{j}$ ], and [he to whom the Son will reveal him $\left.\left.{ }_{i}\right]\right]$.'

a. Nehor-k ez-taki [...] nor d-en Aita, [[Semea-k baizen], nobody-E NEG-knows who is-en Father Son.sG-E but eta [nor-i ere Semea-k manifestatu nahi uka-nen and who-D ere Son.sG-E impart want AUX-PROS bai-trauka]].

(Leiçarraga 1571)

bait-〈A3D3E3〉

Lit., '... and to-whomever the Son will want to reveal (him).'

b. Nihor-k ez daki [...] nor d-en Aita [[Semea-k nobody NEG knows who is-en Father Son.sG-E baizen] eta [nor-i ere Semea-k agertu nahi-ko but and who-D ever Son.sG-E reveal want-Pros bai-dio, eta har-k baizen]] (Haran. 1740) bait-〈A3D3E3〉 and DEM-E but

Lit., '... [[but to the Son] and [but to whom the Son ${ }_{j}$ will want to reveal $\left.\operatorname{him}_{i}\right]_{k}$ and $\left.\left.h e_{k}\right]\right]$ ]'

Constructions like (29a) are also attested in original texts, cf. (30):

(30) (Munduko gauza guztiek kondenatzen dute alferra.)

... Bertze guztie-k enplega-tzen [d]ute bere denbora,

other all.PL-E employ-IMPF bait-〈A3E6〉 their time.sG

[zer-tako egin-ak bai-tira, har-tan]

what-for made-PL bait-are DEM-LOC

(Ax. [1643] 1968: \$241)

'(All the things in the world condemn lazy people.) [...] apart from hem, everybody else spends their time in that for which they are/have been created.' (Lit., 'they spend their time for what they have been made, in that.')

Importantly, the second conjunct in (29b), [nori ere Semeak agertu nahiko baidio, eta hark baizen] also contains eta 'and', just like (26) above. As for its structural position, it it very difficult to imagine that this linker could be inside a nominal expression consisting of a nor-free relative on its left, and a demonstrative on its right, not to mention the pause. Things become clearer once we assume that (30) is derived via movement from a structure like (31): all the material that follows the CorP and the pronominal correlate hartan, between square brackets, raises to the immediate left of the wh- word zertako 'what-for' to yield (30). In (31a), which represents the relevant structure before movement, the landing site, marked by a dash, can be taken to be the specifier of one of the iterable Topic Phrases of Rizzi (1997). (31b) represents the structure after movement: it crucially contains a trace at the end (see Rebuschi 2006 for details). 
(31) a. Bertze guztie-k - [ [ ${ }_{\text {CorP }}$ zer-tako eginak bai-tira $]$, other all.PL-E what-for done.PL bait-are [har-tan [enplegatzen dute bere denbora]]] DEM-LOC use-IMPF 〈A3E6〉 their time.sG

b. Bertze guztie-k [enplega-tzen dute bere denbora] ${ }_{i}$ other all.PL-E use-IMPF 〈A3E6〉 their time.sG [[ ${ }_{\text {CorP }}$ zer-tako egin-ak bai-tira $]$, [hartan $\left.\left.t_{i}\right]\right]$ what-for done-PL bait-are DEM.LOC

Returning to (29b) now, the predicate ez daki nor den Aita 'does not know who the Father is' must simply be assumed to simultaneously bind two empty positions, following the two occurrences of baizen 'except'. This is clear case of an ATB phenomenon, understandable if the conjuncts are not two DPs, but two clauses, just as the string zertako eginak baitira, hartan in (30) is in fact a clausal structure with a gap, as shown in (32a). Likewise, the correct representation of the relevant part of (29a) must be assumed to be as in (32b), since neither eta nor the pronominal correlate are obligatory.

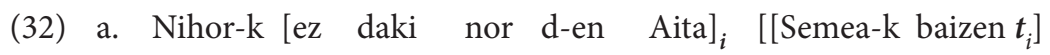
nobody NEG knows who is-(e)n Father Son.sG-E but eta [nor-i ere Semea-k agertu nahi-ko bai-dio, and who-D ever son.SG-E reveal want-PROs bait-〈A3D3E3〉 eta har-k baizen $\boldsymbol{t}_{i}$ ]]and DEM-E but

b. Nehor-k [ez-taki nor d-en Aita $]_{i}$, [[Semea-k nobody-E NEG-knows who is-en Father Son.sG-E baizen $\boldsymbol{t}_{i}$ ], eta [nor-i ere Semea-k manifestatu but and who-D ever Son.sG-E impart nahi ukan-en bai-trauka $\left.\boldsymbol{t}_{i}\right]$. $^{15}$ want AUX[TR]-PROSP bait-〈A3D3E3〉

\subsection{Differences between CorPs and SFRs}

Taking into account the fact that all the Basque dialects easily topicalise SFRs, and that even in Northern Basque, the latter are less marked stylistically, it is natural to find translations which display either construction for the same original text, a fact illustrated in (33).

(33) Mt 10,40 - LV: 'Qui recipit vos, me recipit.' / KJV: 'He that receiveth you receiveth me.'

a. $\mathrm{Zu}-\mathrm{ek}^{16}$ rezebi-tzen zaituzte-n-a-k, ni you[5’] receive-IMPF 〈A5'E3〉-en-SG-E me rezebi-tzen nau. receive-IMPF 〈A1E3〉 
b. Nor-k ere zu-ek har-tzen bait-zaituzte, who ever you[5'] receive-IMPF bait-〈A5'E3〉 eta har-k ni har-tzen nau. and DEM-E me receive-IMPF〈A1E3〉

(Haraneder 1740)

c. Zu-ek har-tzen zaituzte-n-e-k, you[PL] receive-IMPF $\langle A 5$ 'E6 6 -en-PL-E

ni naute har-tzen.

me 〈A1E6〉 receive-IMPF

(Duvoisin 1859-65)

However, the fact that CorPs can be paraphrased by SFRs does not constitue evidence that they have much in common syntactically: their internal structure is obviously quite different as the reader can also ascertain.

First, CorPs have an explicit wh-word or phrase in their left periphery, whilst SFRs lack such phrases. They may only have an abstract operator. Second, the complementizer affix associated with the FVF is distinct in the two cases. While SFRs use -(e)n, CorPs feature bait-. The third difference affects syntactic composition. As noted in 2.3. above, SFRs display a Number and D projection (cf. (15)). In the case of CorPs, there is no decisive argument to hypothesize that anything dominates the CP. This difference gives rise to differences when it comes to quantification. As $(34 \mathrm{a}, \mathrm{b})$ shows, SFR can be modified by the universally quantifiers guzia (which is always marked for number and sits in the head of the DP), or oro (which is not marked for number, and is right-adjoined to the DP). Such items can never follow a CorP.

(34) Imit. 3,47,1 - Thomas: Modicum est, et breve omne quod transit cum tempore. Benham: 'Little and short is all that passeth away with time.'

a. Aphurra eta laburra da denbora-rekin iragai-ten little.SG and short.sG is time.SG-COM pass-IMPF de.n guzia. 〈A1〉-en all.sG

(Pouvreau 1669)

b. Egun-e-kin bat-ean itzal-tzen dir-en-ak oro, day-PL-COM one-LOC disappear-IMPF 〈Al〉-en-PL all gauza guti dira eta guti dute irau-ten. (Léon 1929) thing little are and little $\langle\mathrm{A} 3 \mathrm{E} 6\rangle$ persist-IMPF

While CorPs themselves cannot be so quantified, it must be noted that their pronominal correlates in the apodosis can be universally quantified, as shown in $(35 a, b)$.

a. Derradan huts-ik egin gabe zer ere
say[SUBJ]<A3E1 $>$ fault-PART make without what ever
eskiriba-tuko baita euskara-z, hura guztia,
write-PROSP bait-〈A3〉 Basque-INST DEM all.sG


euskaldun-e-n buruzagi bezala, zu-ri dagotzu-la.

Basque-PL-GEN leader as you-D pertains $` A 3 D 5>-C^{\circ}$

'Let me say without making any mistake that whatever will be written in Basque, all that is due to you, as leader of the Basques.'

(Axular [1643] 1964: §5)

b. Mt 7,12 - LV: 'Omnia ergo, quaecumque vultis ut faciant vobis homines, ita et vos facite eis.' / KJV: 'Therefore all things whatsoever ye would that men should do to you, do ye even so to them.

Zer ere beraz nahi bai-tuzue egin

what ever then want bait-〈A $3 \mathrm{E} 5\rangle, \sqrt{ }$ do

diezazuete-n zu-e-i gizone-k, eta $h e-k$

$\left\langle\right.$ A3D5'E6[SUBJ]>-C $\mathrm{C}^{\circ}$ you[5']-D man.PL-E and DEM-PL

guzi-ak egin diotzatzuete zuek ere h-e-i.

all-PL $\sqrt{\text { do }}$ 〈A3D6E5’PL[IMP] y you[5'].E too DEM-PL-D

(Harriet 1855)

The possibility of such quantification suggests to us that in these cases the CorPs must be interpreted as a property. Was it not a property, the ban on vacuous quantification would not be respected.

Turning now to differences between syntactic positions SFRs and CorPs can occupy in the sentence, there are also two salient differences. First, as was remarked in 2.3. SFRs, due to the fact that they contain extended nominal projections, can appear in any position where ordinary DPs occur. In particular, they can be found in argumental positions, as (non-topicalized) subjects or objects. They can also occur in the $\mathrm{CP}$ domain, for example in ordinary topic and focus positions, cf. (21)-(24) above. Correlative protases on the other hand cannot be focussed: if their content must be focussed, it is the pronominal correlate which occupies the focus position in the left periphery (see Rebuschi \& Lipták (to appear) for examples and discussion). As a second difference it must be noted that the presence of eta lit. 'and' as a linking element between relative and main clause is only attested with correlatives (cf. 26). When they are left-peripheral, SFRs cannot be linked to the main clause by the word eta.

Before closing this section, it must be noted that although SFRs and CorPs are clearly distinct syntactically, the two types of clauses can be - quite unexpectedly - coordinated with each other (cf. (20)). Here again, the conjoined phrases do not yield two entities, or two generalised quantifiers, but two properties narrowing down the relevant domain. Now consider (36), from the Easternmost Northern dialect, Souletin Basque. The first domain is provided by a CorP, and is next restricted by an SFR, whilst 
in (37) (in Baztanese, spoken in Spanish Navarre, but very close to Labourdin Basque), it is the opposite situation that obtains:

(36) Imit. 1,20,4 - Thomas: O, qui omnem vanam sollicitudinem amputaret, et duntaxat [...] divina cogitaret, [...] quam magnam pacem et quietem possideret. / Benham: 'O how great peace and quiet should he possess, who would cast off all vain care, and think only of [...] divine things [...]!'

O [[nur-k ere khen be-litzake arranküra banuak

Oh who-E ever $\sqrt{ }$ remove bait-〈A6E3 $>$ worry vain.PL

oro], eta [zelüko ... gaize-tan baizik gogua ezar-tzen

all and heavenly thing.PL-LOC but mind.sG put-IMPF

e-li-an-a-k]], ala be-iliro har-ek bake

NEG-〈A3E3〉-en-SG-E PRTC bait-〈A3E3[POT]〉 DEM-E peace

eta phausü handi bat goza!

(Maister 1757)

and rest big one $\sqrt{ }$ enjoy

(37) Mt 5,19 - LV 'Qui ergo solverit unum de mandatis istis minimis et docuerit sic homines, minimus vocabitur in regno caelorum [...]'

KJV: 'Whosoever therefore shall break one of these least commandments, and shall teach men so, he shall be called the least in the kingdom of heaven [...]' Orrengatik, [ $[$ nor- $k$ ere aus-ten bai-tu manamendu

for-that, who-E ever break-IMPF bait-〈A3E3〉 commandment

o-tarik ttipiena], eta [ola gizone-i

those-ABL smallest.sG and thus man.PL-D

erakus-ten du-en-a]], soil ttarr-a dei-tu-a iza-in

teach-IMPF 〈A3E3〉-en-SG mere small-SG call-PRF-SG be-PROS

da (pro) zeruetako erreinua- $n$ [...]. (Echenique, c. 1857)

〈A3〉 heavenly kingdom.sG-LOC

Lit., 'Who[sG] ever breaks... and the - that teaches[sG], (pro[+SG]) will[sG] be called...'

Such examples of syntactically unbalanced coordination clearly show that CorPs and SFRs must share one important feature, and, as was suggested in 2.5 for coordinated SFRs and appositive relatives, this feature may well be that both types of structures can denote properties.

\section{Differences between CorPs and other dependent wh-clauses}

Up to now, we have identified embedded questions (cf. 5a) and appositive relatives as non-independent wh-clauses distinct from CorPs. Leaving aside exclamatives (cf. 8b), there are three more types of constructions that are semantically/syntactically similar 
to correlatives: indefinite free relatives, unconditional clauses and interrogatives. This section will review these types of constructions in turn. It will be shown that correlatives differ from all these. The section will close with a recapitulation that summarizes all the differences, together with the differences discussed in the previous section, concerning relative clauses.

\subsection{Indefinite free relatives}

The expression "indefinite free relatives" (henceforth IFR) has been introduced by Caponigro (2001) and Grosu (2004). It refers to wh-clauses found in existential contexts. The wh-clause can be preceded by existential 'be' or its two-place equivalent 'have. The following examples are borrowed from Caponigro (2001):

(38) a. Cè [chi dice sempre di sì].

(Italian) there's who says always of yes 'There's somebody/people who always says/say yes.'

b. Est' [s kem pogovorit'].

(Russian) is with whom to.talk

'There is somebody with whom one could talk.'

c. Van [kivel beszélni]. is who-comto.talk

'There is/are someone/people to talk to.'

(39) a. Non aveva [dove nascondersi in caso di pericolo]. not had where to.hide.himself in case of danger 'He didn't have a place/places where he could hide in case of danger.'

b. Toj ima [s kogo da govori]. (Bulgarian) he has with whom PRTCL talk.3sG 'He has somebody to talk to.'

c. eyn li [im mi le-daber]. (Modern Hebrew) not.is to.me with who to.talk 'I don't have anybody to talk to.'

Basque displays the same possibilities, as illustrated by the following excerpts. The respective verb forms are either finite, and can therefore receive a $\mathrm{C}^{\circ}$ affix, cf. (40)-(42), or non-finite, cf. (43). In the latter case the absence of any auxiliary blocks the appearance of aspectual suffixes on the lexical verb's root (represented by ' $V$ ' in the glosses), and the presence of comps like bait- or -en.

(40) Mat 8,20 - LV: 'Filius autem hominis non habet ubi caput reclinet.' KJV: 'But the Son of man hath not where to lay his head.' 
Baina gizona-ren Semea-k ez-tik

but man.SG-GEN son.sG-E NEG-has[ALLOC $]^{17}$

[non bere burua reposa deza- $n$ ].

(Leiçarraga 1571)

where his head. sG لlay 〈AE3[suBJ]〉-en

(41) Imit. III,3,4 - Thomas: Qui habet verba mea et spernit ea, habet qui judicet eum in novissimo die. / Benham (III,3,5): 'He who hath My words and rejecteth them, hath one who shall judge him at the last day.'

Nor-k ere adi-tzen bai-titu ene hitz-ak eta who-E ere hear-IMPF bait-〈A3E3〉 my word-PL and ez-pai-tu he-taz kontu-rik egi-ten, $b a-d u$ NEG-bait-〈A3E3〉 DEM-INST heed-PART do-IMPF PRTC-has

[nor-k hura juiea-tuko du-en azken egun-ean]. who-E DEM judge-PROSP 〈A3E3〉-en last day-SG.LOC

(Lit., 'He who hears my words and does not pay attention to them has who will judge him on the last day.')

(42) Jn 12,48 - LV: 'Qui [... non accipit verba mea, habet qui iudicet eum. / KJV: 'He that receiveth not my words, hath one that judgeth him.'

Ene hitzak onhes-ten ez ditu-en-a-k $b a-d u$

my words receive-IMPF NEG 〈A6E3〉-en-SG-E PRTCL-has

[nor-k juia-turen bai-tu].

who-E judge-PROs bait-〈A3E3〉

(Duvoisin 1859-65)

(43) [same verse as in (40)]

a. Gizona-ren Semea-k ez $d u$ [non burua pausa]. man.sG-GEN Son.sG-E NEg has where head.sg $\sqrt{ }$ put Lit., 'But the Son of Man does not have where to put/rest (his) head.'

(Haraneder 1740)

b. Gizona-ren Semea-k ez $d u$... [non etzan burua]man.sG-GEN Son.sG-E NEG has where لlay head.sG (ditto)

(Duvoisin 1959-65)

In today's Basque, structures like (43), where the verb is unmarked for aspect and the auxiliary is elided, are preferred, although the subjunctive of (40) and the future (indicative) of (41) and (42) are still acceptable. ${ }^{18}$

When we compare IFRs to CorPs, we can notice that their internal properties, albeit somewhat similar, is still not completely identical. IFRs allow the mood to be subjunctive rather than indicative as shown above ${ }^{19}$ and they also differ with respect to the presence of the particle ere, which has been translated into 'ever' in this sort of context, but which may also mean 'even' and 'also/too'. While this particle characterizes CorPs (see Section 3), the reader will have noticed that ere is absent in all of the foregoing examples of IFRs. It needs to be noted that ere is not completely ruled out here: my 
informants do not reject the presence of this particle in (44), for example. Rather, they find it slightly degraded:

(44) Gai hor-taz, ez dut zer-taz (?ere) mintza. matter DEM-INST NEG I.have what-INST ere $\sqrt{\text { speak }}$

'I do not have anything to say on that matter.' (Lit., 'On that subject, I don't have what(ever)-about (to) speak.')

Returning the first point, note that the ellipsis of the aspectual suffix and the associated auxiliary is always possible in correlative protasis $>$ and apodosis - and is even the main, if not sole, possibility of forming (comparative) CCSs in central, Guipuzcoan, Basque. See (45), which is quite natural in Northern Basque too:

(45) Nola bizi, hala hil.

how $\sqrt{\text { live }}$ thus $\sqrt{\text { die }}$

'One dies the way one has lived.'

(Zavala 1985: II, 70, \#2223)

IFRs and CorPs are also quite different from the point of view of external properties. When it comes to syntactic position, IFRs must appear post-verbally so as to be in the scope of the existential verbs 'be' and 'have', while CorPs are by definition situated in the left periphery of the main clause. IFRs cannot be paraphrased by SFRs, either, although the latter, contrary to CorPs, can also appear post-verbally.

\subsection{Unconditional clauses}

The phrase "unconditional clauses" is, as far as I know, due to Zaefferer $(1990,1991)$. This nice term refers to "no matter..." clauses, i.e. clauses that explicitly express the idea that their content is, contra what could be expected, not relevant to the truth value of the apodosis (cf. Izvorski 2000, who labels them "free adjunct free relatives", and Tredinnick 2003). They are relevant to our concerns for at least two reasons.

In the earliest centuries of the history of Basque, unconditional sentences always had the same internal form as correlatives, see (46), or (47), which dates back to the late 19th century. These sentences are still judged acceptable today.

(46) Rom 2,1 - LV: 'Propter quod inexcusabilis es o homo omnis qui iudicas [...].' / KJV: 'Therefore thou art inexcusable, o man, whosoever thou art that judgest [...].'

a. Halalotz eskusa gabe aiz o gizona therefore excuse without thou.art o man.sG nor ere bait-aiz bertzeak juieatzen ditua-n-a. who ever bait-thou.art other.PL judge.IMPF 〈A6E2〉-en-SG 
b. Hargatik zare ezin-esenkusatuzkoa, o gizona, because.of.that you.are inexcusable.sG o man.sG nor ere bait-zare bertze-ak jujea-tzen ditutzu-n-a who ere bait-you.are other-PL judge-IMPF $\langle\mathrm{A} 6 \mathrm{E} 5$ - -en-SG

(Haraneder 1740)

(47) Nor ere bait-zare, [...], barkha zadazu ene bizitasuna... who ever bait-you.are $\sqrt{\text { forgive }\langle A 3 D 1 E 5[I M P]}>$ my briskness.sG 'Who ever you are, my friend, forgive my briskness.'

(Hiriart-Urruty 1891)

Paraphrases of these clauses appeared in the 18th century (today, they are less marked stylistically as rhetorical); they contain a free choice indefinite, and their FVF is in the subjunctive mood, as in (48).

(48) Rom 2,1 [same NT verse as in (46)]

a. Hargatik, o gizon juiatzen hari haiz-en-a, because.of.that o man judging busy thou.art-en-SG nor-nahi izan hadien, ez haiz aitzakia-dun. anybody be 〈A2[SUBJ] $>$ NEG thou.art pretext-having (Lit., 'Therefore, o man that judges [others], be you anybody, you have no excuse.')

(Duvoisin 1859-65)

b. ...zu-k, juje-a-ren-a egi-ten duzu-n-a-k, you-E the- $\varnothing$-of-the-judge-SG do-IMPF $\langle\mathrm{A} 3 \mathrm{E} 5$-en-SG-E nor-nahi izan zaitez-en, estakururik ez duzu. anybody be $\langle\mathrm{A} 5[\mathrm{SUBJ}]\rangle$-en pretext-PART NEG you.have

(Etchehandy 1999)

The free-choice indefinites of subjunctive unconditional sentences are formed with a wh-word or root (belonging to the "interrogative" paradigm, not the relative one), either followed by nahi lit. 'want', or preceded by edo (conjunctive) 'or'. The case suffixes always follow the wh-word in edo-... forms, but appear either on the wh-item, or on nahi, and even sometimes on both, according to the subdialects, e.g., in the ergative: edo-nor.k / nor.k-nahi / nor-nahi.k / nor.k-nahi.k (more complex forms can also be found).

Unconditionals can also be found as paraphrases of CorPs and left-peripheral SFRs. This possibility is illustrated in (49a-c), where the similarity of meaning is underlined by the parallelism of form both in the Elizabethan authorised version and in the other Basque translations given. ${ }^{20}$

(49) Mt, 12,32 - LV: Et quicumque dixerit verbum contra Filium hominis, remittetur ei; qui autem dixerit contra Spiritum Sanctum [...]. / KJV: 'And whosoever speaketh a word against the Son of man, it shall be forgiven him: but whosoever speaketh against the Holy Ghost, it shall not be forgiven him [...].' 
a. Eta nor ere mintza-turen bai-ta gizona-ren and who ever speak-Pros bait-〈A3〉 man.sG-GEN Semea-ren kontra, barka-turen zaio har-i; Son.SG-GEN against forgive-PROSP 〈A3D3〉 DEM-D baina nor ere mintza-turen bai-ta Spiritu but who ever speak-Pros bait-〈A3〉 ghost saindua-ren kontra, et-zaio barka-turen har-i. holy-GEN against NEG-〈A3D3〉 forgive-PROSP DEM-D

(Leiçarraga 1571)

Lit. 'And who(ever) will speak against..., it shall be forgiven to that one; but who(ever) ..., it shall not be forgiven to that one.'

b. Eta nor-nahi mintza dadien gizona-ren Semea-ren

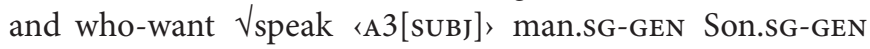
kontra, barkhakizun da $\varnothing$; bainan Izpiritu saindua-ren against forgivable is pro but ghost holy.sG-GEN kontra mintza-tu daite-n-a-ri et-zaio [...] against speak-PROS〈A3[FUT]〉-en-SG-D NEG-〈A3D3〉 barkha-turen. (Duvoisin 1859-65) forgive-PROS (Lit., 'And [should] anyboby speak against the Son of man, he/it can be forgiven; but to who(m)ever has spoken against the Holy Spirit, it shall not be forgiven.')

c. Gizona-ren Semea-ren kontra mintza-tuko d-en-a-ri man.SG-GEN son.SG-GEN against speak-PROs 〈A3〉-en-SG-D barkatua izan-en zaio. Izpiritu Saindua-ren kontra forgiven.sG be-PROS〈A3D3〉 Ghost Holy.SG-GEN against mintza-tuko $d$-en-a-ri aldiz et-zaio speak-PROs 〈A3〉-en-SG-D however NEG-〈A3-D〉3 barka-tu-a izan-en [...] (Léon 1946) forgive-PRF-SG be-PROS Lit., 'To the (one) that will speak...; to the one that will speak...'

\subsection{Appositive relatives, CorPs and interrogatives: The wh-phrase}

When comparing correlatives and wh-constructions, interrogatives also need to be mentioned. These differ from CorPs most clearly in their wh-phrase.

We have already mentioned that CorPs select their basic wh- words, nor 'who' and zer 'what', from the interrogative paradigm. We have also mentioned that these words cannot be used as relative pronouns in appositive clauses, whether these clauses are adjoined to a DP or the E-type pronoun haina, or whether they are extraposed. For a full description of the facts, more factors must be taken into account. 
First, the general relative pronoun zein- can also be used as an interrogative, but its use is usually restricted to closed (D-linked) sets, which already belong to the universe of discourse. Accordingly, normal translation of zein is 'which one(s). ${ }^{21}$ Starting from the 18th century, however, an important distinction has been made between two of its occurences. Its bare form that functions as an interrogative pronoun is also used in CorPs. A form marked for number on the other hand is used as a relative pronoun, as shown in the following examples.

(50) [Correlative use: invariable/no number indicated] Mt 26,48 - LV: 'Quemcumque osculatus fuero, ipse est!' KJV: 'Whomsoever I shall kiss, that same is he'.

Zein-i ere musu ni-k eman-en bai-diot, which-D ever kiss I-E give-PROs bait-〈A $3 \mathrm{D} 3 \mathrm{E} 1$ 〉

eta hura diteke

(Haraneder 1740)

and DEM it.will.be

(51) [Relative use: SINGULAR]

Mt 1,21- LV: 'Pariet autem filium, et vocabis nomen eius Iesum.'

KJV: 'And she shall bring forth a son, and thou shalt call his name Jesus.'

Erdi-ko da seme batez, zein-a-ri ema-nen

bear-PROS 〈A3〉 son one.INST zein-SG-D give-PROS

bai-diote izen-a Jesus.

(ibid.)

bait-〈A3D3E6〉 name-SG Jesus

(Lit. 'She will bear a son, to whom they will give the name Jesus.)

(52) [Relative use: PLURAL]

Lk 26,48 - LV: '[...] non omnes capiunt verbum istud sed quibus datum est.' / KJV: 'All men cannot receive this saying, save they to whom it is given.'

Ez dire guzi-ak gai hortakotz, hainak baizen,

NEG they-are all-PL able for.that such.PL but

$z$ ein-e-i eman izan baitzaie.

(ibid.)

zein-PL-D given AUX-PERF bait-〈A3D6〉

$(53 \mathrm{a}, \mathrm{b})$ illustrate the use of bare zein as a relative pronoun in the 16 th and 17 th centuries. (Haraneder 1740 and Duvoisin 1859-65 have the plural form zein-ak in their translations of (53a), so that their FVFs naturally agree in plurality.)

(53) a. Mt 7,15- LV: 'Attendite a falsis prophetis, qui veniunt ad vos in vestimentis ovium...'/ KJV: 'Beware of false prophets, which come to you in sheep's clothing...'

Begirauzue [...] profeta falsue-tarik, zein

beware[IMP]〈A3-E5’ prophet false.PL-ABL zein

ethor-ten bai-tirade zu-etara ardi abitu-rekin...

come-IMPF bait-〈A6〉 you[5]-to sheep clothing-COM

(Leiçarraga 1571) 
b. Nola ageri baita Ejipto-ko Piramidet-an, how apparent bait-is Egypt-GEN pyramid.PL-LOC zein eragin bait-zit-uen errege Faraon-ek... zein build-FACT-PRF bait-〈A6E3[PAST]〉 king Pharaoh-E

(Lit., '[...] How [clearly] it appears in Egypt's pyramids, which Pharaoh had made build.')

Next to form, there is also another property that distinguishes interrogative and correlative wh-words from those used in relative clauses: their position in the clause in which they appear. Thus, whereas relative pronouns must be clause initial (cf. Rizzi (1997), and much ensuing work), interrogative and correlative wh-items need not be. An interrogative wh-word can be preceded by various topicalised phrases, as shown in (28a) above, where the subject pronoun is topicalised. In the next two examples, the same is shown for CorPs. In (54) a direct object precedes the wh-phrase, and in (55), a quantifier does.

(54) Lk 8,21 - LV: 'Mater mea et fratres mei hi sunt, qui verbum Dei audiunt et faciunt.' / KJV: 'My mother and my brethren are these which hear the word of God, and do it.'

[Jainkoa-ren hitza nor-k ere entzu-ten bait-du

God-GEN word.sG who-E ever hear-IMPF bait-〈A3E3〉

eta obra-tzen], hura da ene ama eta ene aneia-

and work-IMPF DEM is my mother and my brother

(Léon 1946)

(55) Holakoe-tan [bakotxa-kzer ere bait-du bere such.PL-LOC each.SG-E what ever bait<A3E3> himself

baitan], eta har-tarik ari da.

(Hiriart-Urruty [1893] 1972: 49) in and that-ABL busy is

'In such cases, whatever anyone has in himself, that is what he uses.'

Lit., 'each/every one whatever s/he has...'

Finally, we must also mention a difference between the distribution of the wh-phrases in CorPs and in questions. While focussed phrases can intervene between the whword and the finite verb form in CorPs, they cannot do so in an interrogative sentence, regardless of whether the latter is embedded or not. This is shown in (56) and (57), where the focussed adjuncts are in italics and small caps.

(56) Gal 6,16 LV 'et quicumque hanc regulam secuti fuerint pax super illos...' / KJV 'And as many as walk according to this rule, peace be on them...'

Eta nor ere reglahun-en araura ebil-ten and who ever rule that-GEN according behave-IMPF bai-tirade, bakea izan-en $d a$ hai-e-n gainean... ${ }^{22}$ bait-〈A6〉 peace.SG be-PROSP〈A1〉DEM-PL-GEN on 
(57) Mt 19,29 - LV: 'Et omnis, qui reliquit domos vel fratres [...] aut agros propter nomen meum, centuplum accipiet...' / KJV 'And every one that hath forsaken houses, or brethren [...] or lands, for my name's sake, shall receive an hundredfold...'

Eta nor-k ere ene izenaren aria- $z$ utz-iko bai-titu

and who-E ever my name's sake-INST leave-PROs bait-〈A6E3〉

etxe-a, edo anai-ak [...] edo lurr-ak, haina-k

house-SG or brother-PL or land-PL such.SG-E

ehunkun iza-nen $[. ..] \mathrm{du}$.

(Duvoisin 1859-65)

hundredfold have-PROS 〈A3E3〉

Concerning the other constructions handled in this section, a focussed element can also intervene between a wh-word and the FVF in IFRs, cf. (41) and (43a), indicating some relationship between CorPs and IFRs. In the case of unconditional clauses, focus cannot intervene between wh-word and FVF, since the wh-word is locally focussed and must therefore be left-adjacent to the inflected verb.

\subsection{Summary of findings and the structure of CorPs}

In this 4th section, we have described and compared five types of (non-independent) wh-clauses in Basque: appositive relatives, wh-questions, correlative clauses, indefinite free relatives and unconditional clauses. Their properties are listed Table (1).

Table 1. Comparative properties of CorPs and other non-independent wh-clauses

\begin{tabular}{|c|c|c|c|c|c|}
\hline & $\begin{array}{c}\text { Appositive } \\
\text { relative clauses }\end{array}$ & $\begin{array}{l}\text { Embedded } \\
\text { questions }\end{array}$ & $\begin{array}{c}\text { Correlative } \\
\text { protases }\end{array}$ & IFRs & $\begin{array}{c}\text { Unconditional } \\
\text { clauses }\end{array}$ \\
\hline wh-elements & $\operatorname{zein}^{*}(a) /{ }^{*}$ nor & $z \operatorname{ein}\left({ }^{*} a\right) /$ nor & $z e i n\left({ }^{\star} a\right) /$ nor & nor & nor \\
\hline $\begin{array}{l}\text { obligatory initial } \\
\text { position of wh-item }\end{array}$ & yes & no & no & no & no \\
\hline $\begin{array}{l}\mathrm{C}^{\circ} \text { affix on FVF } \\
\text { presence of ere after } \\
\text { the wh-word or phrase }\end{array}$ & $\begin{array}{l}\text { bait- } \\
\text { no }\end{array}$ & $\begin{array}{c}-e n /^{*} \text { bait- } \\
\text { no }\end{array}$ & $\begin{array}{l}\text { bait-/?-en } \\
\text { preferred }\end{array}$ & $\begin{array}{c}\text {-en/bait } \\
\text { no }\end{array}$ & $\begin{array}{c}\text { bait- } \\
\text { optional }\end{array}$ \\
\hline $\begin{array}{l}\text { obligatory left-adjacen- } \\
\text { cy of wh-item with } \\
\text { respect to FVF }\end{array}$ & no & yes & no & no & no \\
\hline $\begin{array}{l}\text { position to the right of } \\
\text { the main clause's FVF }\end{array}$ & possible & possible & impossible & $\begin{array}{l}\text { obliga- } \\
\text { tory }\end{array}$ & possible \\
\hline $\begin{array}{l}\text { insertion of eta } \\
\text { in-between the protasis } \\
\text { and the apodosis }\end{array}$ & (DNA) & (DNA) & possible & (DNA) & impossible \\
\hline $\begin{array}{l}\text { possible paraphrase by } \\
\text { a SFR }\end{array}$ & yes & no & yes & no & no \\
\hline
\end{tabular}


The first four properties concern the internal structure of the compared clauses, the next three their combinatorial properties, and the last one, their ability to be paraphrased by an SFR.

As can be seen, CorPs clearly differ from every other type, in that:

i. they can be linked to the apodosis by the word eta;

ii. they must occur in the left periphery of the main clause - if the argumentation in 3.2 above is correct, this is simply because they are directly merged there.

Concerning other properties, correlative clauses they are similar to embedded questions as far as the choice of their wh-element is concerned. Yet, there are differences, too. The wh-phrase is preferably followed by ere 'ever' in CorPs, which cannot appear either in embedded or in root questions. Correlatives also share some properties with indefinite free relatives, except for the presence of ere, and their respective positions with respect to the main clause. Finally, correlatives and appositive relatives are the only types of clauses that can be paraphrased by an SFRs.

The other constructions also differ from each other in various ways. For instance, the fact that the wh-phrase must be left-adjacent to the FVF in its own minimal clause, and the fact that the $\mathrm{C}^{\circ}$ affix cannot be bait-in embedded interrogatives, clearly sets these apart from the other types. Note by the way that the $\mathrm{C}^{\circ}$ suffix -en in CorPs, which is normal in the varieties spoken across the French-Spanish border, is also, albeit very rarely, attested in Northern Basque. (59) illustrates this point, wich justifies the question mark in table (1), 3rd line.

(58) Lev 24,19 LV: 'Qui inrogaverit maculam cuilibet civium suorum sicut fecit fiet ei.' / KJV: 'And if a man cause a blemish in his neighbour: as he has done, so shall it be done to him.'

[Nor-k ere bere herritarretarik edozein-i gaizki egin

who-E ever his neighbours.ABL anyone-D evil do.Pros

bait-dioke], [[nola bera-k egin du-en],

bait-〈A3D3E3〉 how he.himself-E do-PRF 〈A3E3〉-en

hala egin-a izan-en zaio]].

(Duvoisin 1859-65)

thus do.PRF-SG be-PROS 〈A3D3〉

On the other hand, the differences between IFRs and unconditional clauses seem fairly small, in spite of what seems to be irreducible semantic differences between them. More work is necessary to derive at least some of those bundles of properties from more abstract principles.

A word is also in order concerning the internal syntax of correlative clauses. We can infer from the foregoing discussion that the structure of CorPs from the 17th century on can best be captured by the representation in (59). The basic idea is that the wh-item in these clauses is located in the specifier of a special Topic Phrase. The head of this TopP is normally lexically realised by ere. This optionally visible head may take a FocusP or, more directly and more often, a Finiteness Phrase (FinP) as its complement. 
For cases like (45), I assume a possible zero realisation of the inflectional material within the latter. TopP can itself be dominated by other TopP (see Rizzi 1997).

(59) The left periphery of CorPs

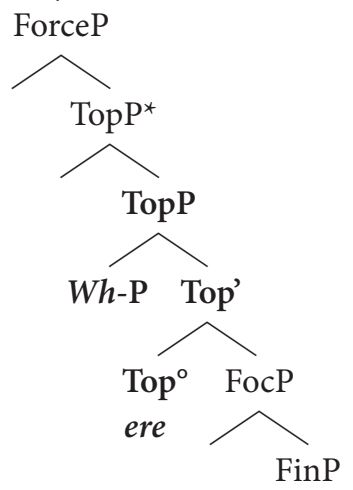

For a more detailed representation concerning the presence of quantifiers, illustrated in (55), as well as the position of multiple wh-phrases, when present, see Rebuschi and Lipták (to appear).

\section{Correlative protases and conditionals}

It is well-kown that complex correlative sentences whose tense is generic or habitual can be paraphrased by conditional sentences whose protases contain either an indefinite pronoun like somebody, something, or a NPI like anybody, anything. In this section, we turn to a comparison between correlatives and such conditionals. We will show that correlatives are not only paraphrasable by conditionals, but that there are intriguing convergences in the very morphological material used in both types of sentences.

\subsection{Basque conditionals}

Let us start with a brief description of conditional sentences and their basic semantic similarity with other types of sentences. Basque conditional clauses always have a morpheme $b a$ - 'if' prefixed to their finite verb form. This $b a$ - may be given some emphasis by being replaced by balinba (or preceded by the orthographically independent word balin); ${ }^{23}$ moreover, an allomorphic variant of balin, baldin (and longer derived forms, such as baldin-eta, baldin.eta.ria $(k))$ may occupy the initial position in the clause. ${ }^{24}$ Although it is rare to find both initial baldin and the emphatic balin.ba together, it is not impossible, cf. $(60 \mathrm{a}, \mathrm{b})$, where the subordinate clause is, however, to the right of the main clause. 
(60) Imit. I,23,4 - Dabit namque magnam fiduciam moriendi perfectus contemptus mundi. [...] / Benham: 'For a perfect contempt of the world, a fervent desire to excel in virtue [...] [is something] which shall give great confidence of a happy death.'

a. Heriotze on eta dohatsu bat-en esparanza har death good and happy one-GeN hope $\sqrt{ }$ receive ahal dezakegu baldin balin-ba-dugu mundua-rentzat can 〈A1E4[РОT] > baldin balin-if-we.have world.sG-for mezprezio oso bat.

(Chourio 1720) disdain full one

(Lit. 'We can have the hope of a good and happy death if we have total contempt for the world.')

b. Ba-dakite nehon-dik neholere ez PRTC-they.know nowhere-ABL in.no.way NEG detzazkegu-la guk hemen bazterre-tako berriak $\left\langle\mathrm{A} 6 \mathrm{E} 4[\mathrm{PO} \mathrm{T}]\right.$ - $\mathrm{C}^{\circ}$ we-E here place.PL-GEN news.PL xuxen eman eskuaraz, zoin beren egunetan, correctly give Basque-INST each their days-LOC baldin ez balin-ba-dugu igortzaile-rik. baldin NEG balin-if-we.have sender-PART

(Hiriart-Urruty [1893] 1995) 'They know that we here can absolutely not give correct news from every place, from day to day, if we have no correspondent.'

\subsection{CCSs as paraphrases of conditional sentences}

Resuming our review of various translations of the same texts, the following examples show the various ways in which Latin indefinite conditional sentences could be translated: the translations either provide a similar conditional clause (cf. 61a,b), or a Corp. (cf. 62), or yet a left-peripheral SFR (cf. 63). ${ }^{25}$

(61) Jn 14,23 - LV: 'Si quis diligit me, sermonem meum servabit [...]' KJV: 'If a man love me, he will keep my words [...]'

Imit II,1,2- Benham: 'if any man loveth me he will keep my words [...]'

a. Baldin norbeit-ek on ba-darizt ni-ri, ene baldin somebody-E good if-he.finds me-D my hitz-a begira-turen du. (Leiçarraga 1571: conditional) word-sG keep-PROs 〈A3E3〉

b. Nihor-k maite $b a$-nau, begira-tuko du ene hitza. anybody-E love if-〈A1E3〉 keep-PRos 〈A3E3〉 my word.sG (Pou. 1669: conditional) 
(62) Ni maite nau-en-a-k ene hitz-ak beira-tuko ditu ... me love 〈A1E3〉-en-SG-E my word-PL keep-PROSP 〈A6E3〉 (Lit., 'The - that loves me...')

(Chourio 1720: SFR)

(63) Nurk ere ni maite bei-nai, ene hitzak who-E ere me love bait-〈A1E3〉 my words begira-türen dütü. (Maister 1757: CorP) keep-PROs 〈A6E3〉 (Lit., 'Whoever loves me...')

Although the examples above are chronologically ordered, the variation displayed is not diachronical. Other excerpts would show a different distribution of the syntactic variants, as witnessed by the other translations I have found of Jn 14,23. To wit, Haraneder (1740), Harriet (1855) and Duvoisin (1859-65) use a conditional (both with norbait); Inchauspé (1883), "Ezkila” (1974) and Etchehandy (1999) use a SFR; Haristoy (1896) and Léon (1929, Imit., and 1946, NT) use a CorP.

The reverse situation holds too, as shown in (64): here the Latin text, which contains first a universally quantified left peripheral FR, and second a CorP, is translated into two conditional sentences. Haraneder's and Harriet's translations are added, because their first protasis $>$ is, morpho-syntactically, an unconditional clause.

(64) Mt, 12,32 - LV: Et quicumque dixerit verbum contra Filium hominis, remittetur ei; qui autem dixerit contra Spiritum Sanctum [...]. /

KJV: 'And whosoever speaketh a word against the Son of man, it shall be forgiven him: but whosoever speaketh against the Holy

Ghost, it shall not be forgiven him [...].'

Norbeit-ek errai-ten $b a$-du solas zerbeit Gizona-ren somebody-E say-IMPF if- $\langle\mathrm{A} 3 \mathrm{E} 3 〉$ word some man.SG-GEN

Semea-ren kontra, barka-tuko zaio; norbeitek, aldiz, Sson.SG-GEN against forgive-PROS 〈A3D3〉 somebody-E however errai-ten ba-du Izpiritu Saindua-ren kontra, ez zaio say-IMPF if-〈A3E3〉 Ghost HolyssG-GEN against NEG 〈A3D3〉 barka-tuko $[\ldots]$

(“Ezkila” 1974) forgive-PROS

(Lit. 'If somebody says something ..., it shall be forgiven him; but if he [=somebody] says [it/so] against the Holy Ghost, it shall not be forgiven him.')

(65) a. Nor nahi mintzatu diteken Gizona-ren Semea-ren kontra anybody speak-PRF 〈A3〉-en man.SG-GEN Son.SG-GEN against barkha-tuko zaio; bainan baldin nihor mintzatu ba-da... forgive-PROS 〈A3D3〉 but baldin anybody speak-PRF if- $\langle\mathrm{A} 3$ 〉 (Lit., 'That anybody should have spoken against the Holy Ghost [...]; but if anybody has spoken [...]'

(Haraneder 1740) 
b. Nor nahi gaizki mintza dadin gizonaren [...],

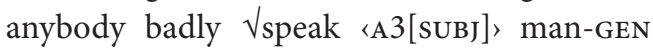

Semea-z, bainan baldin nehor Ispiritu Saindua-z

son.SG-INST but baldin anybody ghost holy.sG-INST

gaizki mintza-tzen ba-da [...]

badly speak-IMPF if-〈A3〉

(Lit., 'let anybody speak evil of the Holy Ghost [...];

but if anybody speaks evil [...]')

(Harriet 1855)

Other translations of this verse are: Leiçarraga (1571) with two CorPs; AnBa (1828, Labourdin Basque) and Iribarnegaray (c. 1860, Low Navarrese) with two conditional protases; Salaberry (1856, Low Navarrese) and Léon (1946, Low Navarrese) with two SFRs; Cazenave (c. 1860, Low Navarrese), with first a CorP and second, an SFR; Etchehandy 1999 ("Navarro-Labourdin"), with first an SFR and second a conditional protasis>; finally, Inchauspé (1856, Souletin) used agentive nominalisation: mintzazalia, lit., 'the speaker' twice.

In fact, the only historical change really attested is the lesser and lesser frequency of appearance of the NPI (nihor / nehor 'anybody' or 'nobody' according to the context) in conditional protases, as against the indefinite/existential norbait 'somebody'. Note that the latter word was already used in the 16th century, as illustrated by (61a).

\subsection{Correlative and conditional protases: ba- and bait-}

Let us now turn to some properties that correlative and conditional protases share or have shared. Curiously enough, some texts display sentences in which bait- is used instead of conditional $b a$-, and vice versa.

As early as the 16th century, one example of bait- replacing conditional ba- 'if' is attested in the NT's translation.

(66) 1-Jn 4,11 - LV: 'Carissimi, si sic Deus dilexit nos: et nos debemus alterutrum diligere.' / KJV: 'Beloved, if God so loved us, we ought also to love one another'. Maiteak, baldin hunela Iainkoa-k onhets-i bai-kaitu, beloved-PL baldin so God-E love-PRF bait-〈A4E3〉 gu-k ere behar dugu elkar onhetsi. (Leiçarraga 1571) we-E too must $\langle\mathrm{A} 3 \mathrm{E} 4\rangle$ each.other love

A century later, the same construction is still attested, see (67), but bait- can be substituted for ba- even if baldin is not present, as in (68).

(67) Imit. 3,37,4 - Thomas: [...] nisi integra resignatione, et quotidiana sui immolatione prius facta [...] / Benham: '[...] unless they first entirely resign themselves and daily offer themselves up as a sacrifice '..."

Baldin lehenago bere buruaren sakrifizio oso eta baldin firstly their own sacrifice full and 
bethiereko bat-ez ene-ganat diren guziaz eternal one-INST me-towards are-en all-INST abandona-tzen ez-pait-zaizkit...

(Arambillaga 1684) forsake-IMPF NEG-bait-〈A5D1〉

(68) Imit. 3,59 - Thomas: ... si tu ipse non assistas, juves, confortes, consoleris, instruas et custodias. / Benham: '... if Thou Thyself do not assist, help, strengthen, comfort, instruct, keep in safety'

zuk zerorrek [...] lagun-tzen, sustenga-tzen, borthiz-ten, you-E yourself help-IMPF sustain-IMPF strengthen-IMPF argi-tzen eta goarda-tzen ez-pai-nauzu. enlighten-IMPF and keep-IMPF NEG-bait-〈A1E5〉

Besides, in his Grammaire basque, Ithurry ([1895] 1920: 360) notes that Axular (the most acclaimed classical writer in Northern Basque) uses "bait- instead of ba- when conditional 'if' is followed by bezala 'as' and bezanbat 'as much as." But Axular was not the only author to use bait- in morphologically marked conditional contexts (whereby I mean that the subordinators equivalent to 'if' were not enough to licence bait- instead of $b a$-: the very conjugation of the FVF had to be "conditional" in the sense that it roughly corresponded, and still does, to the English preterite with a modal, counterfactual or "irrealis" value). ${ }^{26}$ Thus, the same construction is attested in the 18 th century too, both in the Labourdin and the Souletin varieties of Northern Basque, as shown in (69) and (70).

(69) Halarikan-ere nahi dut Oihenarto-k dio-en-a, egia however want 〈A3E1〉 Oyhenarte-E says-en-SG truth.SG bai-liz bezala besarkatu.

bait-it.were as embrace (Etcheverry of Sare [1712] 1907: 76)

'However, I want to espouse Oyhenarte's thesis [lit., 'what O. says'], as if it were the truth.'

(70) Imit. III,30,3 - Thomas: ... tamquam omnis spes sit ablata emergendi. / Benham: '.. as if all hope of escape were taken away'.

... antik jalkiteko esperantxa osoki galdü bei-liz bezala. there-ABL to.get.out hope.SG completely lost bait-it.were as

(Maister 1757)

Intriguingly, the opposite phenomenon, whereby $b a$-is substituted for bait-, seems to have started only once bait-could no longer replace $b a-$. The first example I have found only dates from the late 18 th century, see (71). ${ }^{27}$

(71) Jn 20,23 - LV: 'Quorum remiseritis peccata, remissa sunt eis; quorum retinueritis, retenta sunt.' / KJV: 'Whose soever sins ye remit, they are remitted unto them; and whose soever sins ye retain, they are retained.' 
Nor-i ere barka-tzen $b \boldsymbol{a}$-diozkatzue bekatuak, ta who-D ever forgive-IMPF $b a-\langle\mathrm{A} 6 \mathrm{D} 3 \mathrm{E} 5\rangle$ > sin.PL, and ha-e-i barka-tuko zaizte, ta nor-i ere ez DEM-PL-D forgive-PROS 〈A6D6〉 and who-D ever NEG ba-diozkatzue barka-tzen ta ha-e-i ez zaizte barka-tuko. $b a-\langle\mathrm{A} 6 \mathrm{D} 3 \mathrm{E} 5\rangle$ forgive-IMPF and DEM-PL-D NEG 〈A6-D6〉 forgive-PROS

(Ubillos 1785: 151)

More examples can be found in the 19th century, see (72), (73), and even in the second half of the 20th century, cf. (74).

(72) Mt 5,19 - LV: 'Qui ergo solverit unum de mandatis istis minimis et docuerit sic homines, minimus vocabitur in regno caelorum; qui autem fecerit et docuerit, hic magnus vocabitur in regno caelorum.'

KJV: 'Whosoever therefore shall break one of these least commandments, and shall teach men so, he shall be called the least in the kingdom of heaven: but whosoever shall do and teach them, the same shall be called great in the kingdom of heaven.'

Artakotz, nork ere aus-ten $b a$-du manamendu ttipi therefore who-E ever break-IMPF $b a-\langle\mathrm{A} 3 \mathrm{E} 3>$ order small otarik bat,... arras ttikia deitua izain da those-ABL one very small.sG called.sG be-PROs «A3 zeruetako erreinuan; bano nork ere egi-ten heaven-GEN kingdom-SG-LOc but who-E ever do-IMPF $\boldsymbol{b} \boldsymbol{a}$-du, eta erakus-ten $\boldsymbol{b} \boldsymbol{a}$-du, ura deitu-a $b a-\langle\mathrm{A} 3 \mathrm{E} 3>$ and teach-IMPF $b a-\langle\mathrm{A} 3 \mathrm{E} 3 〉, \mathrm{DEM}$ called-SG izain da andia zeruetako erreinuan. be-PROS 〈A 1 great.SG heaven-GEN kingdom-SG-LOC

(73) Rom 5,18 - LV: 'Igitur sicut per unius delictum in omnes homines in condemnationem sic et per unius iustitiam in omnes homines in iustificationem vitae.' / KJV: 'Therefore as by the offence of one judgment came upon all men to condemnation; even so by the righteousness of one the free gift came upon all men unto justification of life.'

Beraz nola baten bekhatua-ren bidez kondenamendua-ren

thus how one-GEN sin.sG-GEN via condemnation-GEN

azpira erori $\boldsymbol{b} \boldsymbol{a}$-dire gizon guziak, hala ere bat-en under fallen $b a-\langle\mathrm{A} 6\rangle$ man all.PL thus also one-GEN zuzentasun-a-k zuzen eragin ditu guziak. righteousness-SG-E right made-PRF〈A6-E3〉 all.PL (Duvoisin 1859-65) 
(74) Jn 8,12 - LV: 'Qui sequitur me, non ambulabit in tenebris, sed habebit lucem vitae.' / KJV: 'He that followeth me shall not walk in darkness, but shall have the light of life.'

Nor ere jarraiki-tzen $\boldsymbol{b a}$-zaut, hura ez dabil ilhunbe-tan, who ever follow-IMPF $b a-<\mathrm{A} 3 \mathrm{D} 1>$ DEM NEG walks darkness-LOC baina uka-nen du harek biziko argia. but have-PROS〈A3E3〉 DEM-E life-GEN light.sG

(Soubelet 1969: 104)

\subsection{On the relationship between correlative} sentences and conditional sentences

Bittner (2001) argues that complex conditional sentences are a subkind of complex correlative sentences (on a similar view, see Arsenijević this volume). She bases her conclusion on Marathi examples in which wh-words and the pronominal correlates on the one hand, and the counterparts of 'if' and 'then' on the other exhibit the same pairs of morphemes: $j$ - in the protasis $>$, and $t$ - in the apodosis. However, while conditional sentences are organised on a protasis / apodosis in many, if not all, natural languages, not all languages have correlative sentences in the sense that Burushaski, Hindi, Hungarian, Latin, or Polish have such complex sentences, in particular when the pronominal correlate qualified by the CorP denotes an individual. On the other hand, comparative correlatives are much more frequent (see den Dikken this volume and references cited there), perhaps just as universal as complex conditional sentences are.

It would then be more natural to consider CCSs to be a special subkind of conditional sentences, or, perhaps, to show that both structures are fundamentally similar, with something special to add as far as CCSs are concerned.

From this point of view, it is worth recalling Lafon's (1966) hypothesis, revived by Trask (1997), according to which "originally" ba- and bait- were one and the same morpheme, the former a simplification, and the latter a phonological "hardening" (which can be independently justified) ${ }^{28}$ of the positive assertive particle bai 'yes'. Lafon did not mention the ba-/bait- interchanges described in 5.3, but remarked, among other things, that bait functions either as a suffix in indefinite pronouns (in nor-bait 'someone', zer-bait 'something', non-bait 'somewhere', etc.), or as a subordinating prefix in appositive relatives and in correlative clauses. His general thesis is thus that the nor/ zer paradigm may have been ambiguous between an interrogative and an indefinite pronoun in the prehistory of the language. If left alone, these pronouns would have later specialized as interrogative pronouns, but the insertion of assertive bait-in the sentence would have triggered either its suffixation to the wh-words, thereby forcing their unambiguous reinterpretation as indefinites, or its prefixation to the finite verb 
form, yielding a "subordinate" clause interpretable either as a correlative or a conditional protasis>, as summarized in (75)-(77):

(75) Prehistoric period (I)
a. Nor
dator. ${ }^{29}$
wh-[+hum] comes
'Someone is coming.'

b. Nor dator?

'Who is coming?'

(76) Prehistoric period (II)

a. Nor dator? (same as (75b))

b. ${ }^{N}$ bor bai $(t)$ dator

wh-[+hum] bait comes

'Someone is coming' [cf. modern Basque Norbait ba-dator]

'Someone is coming' [cf. the non-emphatic assertion (77a) below]

(77) Historically attested Basque

a. Norbait dator.

someone comes

'Someone is coming.'

b. Nor (ere) bai(t)-dator...

wh-[+hum] ever bait-comes

'Who(ever) comes...'

c. ??Nor / nehor ${ }^{30} /$ nor.bait ba-dator...

who anybody/ somebody if-comes

'If someone/anyone is coming...'

An independent argument for an autonomous status for bait- at an earlier stage of the history of the language is that, in the oldest printed text, the indefinite/existential norbait, in the ergative case, instead of being followed by the case suffix as it has always been since the 17th century, viz. norbait-ek (with an epenthetic-e-), occurs twice under the form: nor-k bait in Etchepare's poems, cf. (78) (remark also that such examples do not have a universal interpretation, in spite of the presence of ere).

(78) a. Nor-k-bait-ere amoria niri daraut mutha-tu. who-E-bait-ever love(r).SG me-D 〈A3D1E3〉 change-PRF 'Someone has changed my mistress.'

Lit. 'someone has-to-me changed the lover'.

(Etchepare [1545] 1980: VII,7)

b. Nor-k-bait-ere egin deraut malizia handia. who-E-bait-ever do.PRF〈A3D1E3〉 wickedness big.SG 'Someone has done a lot of harm to me.' 
Attractive though it may be, and even adding to Lafon's arguments those of 5.2 and 5.3 above, the proposed reconstruction remains highly tentative to say the least, because there is, as far as I know, no means to connect the indefiniteness of the suffix -bait in the norbait, zerbait indefinite pronoun series, and the complementizer status of baitin relative clauses and CorPs.

Moreover, if both CCSs and conditional sentences do optionally exhibit a syntactic "linker", they are quite distinct: eta in the former case, and the grammaticalized time adverbial orduan 'then' in the latter case.

Finally, whilst it is possible to establish some intuitive connection between bai 'yes' and the stressed ba- of the modern Basque Norbait ba-dator cited in (76b), it is much more difficult to suggest anything of the sort concerning unstressed ba- 'if' and bait-, all the more as the latter two items can be preceded by the negative particle $e z$, which cannot be concatenated with emphatic $b a$. The following examples illustrate negative clauses containing either conditional $b a$ - and protatic bait- respectively.

(79) Imit. 1,2,1 - Thomas: Si scirem omnia quæ in mundo sunt, et non essem in charitate, quid me juavert coram Deo [...]? / Benham: 'If I knew all the things that are in the world, and were not in charity, what should it help me before God [...]?'

a. Mundu-ko gauza guziez jakinsun ba-nintz, eta world-GEN thing all.PL.INST knowing if-I.were and ez ba-nu karitatea, zer probetxu nuke NEG if-I.had charity.sG what benefit I.would.have Jainkoaren aitzinean $[\ldots]$ ?

(Chourio 1720) God-GEN before

b. Nakitzan ordian mündüko gaizak oro, I-know[subj] then world-GEN thing-PL all ez-palin ba-nü ${ }^{31}$ karitatia, zer balio NEG-balin if-I.had charity.sG what value lüke jakite harek [...]? would-have knowledge DEM-E

c. ... karitate-rik $\boldsymbol{e} z$-ba-nu, zer probetxu nuke [...]? charity-PART NEG-if-I.had what benefit I.would.have

(Maister 1757)

(Léon 1929)

As was noted above, according to the texts we have, $b a$ - only began to replace bait- in CorPs after the non-standard use of bait- in conditional protases fell into disuse. Whatever the relevance of that fact is, there are independent facts that tend to show that the similarities between CCSs and (indefinite) conditional sentences may well be due to a late convergence (perhaps prompted by the overall semantic parallelism of the two complex constructions), rather than to a (pre)historic common origin. 
A case in point is provided by the presence of eta that occurs not in between the protasis $>$ and the apodosis of CSSs (i.e. as the head of a special Topic Phrase), but following the wh-item of CorPs on the one hand, or immediately to the right of the would be "pleonastic" baldin of conditional protases on the other. Insofar as CorPs are concerned, the most interesting case is provided by the free relatives whose wh-item is noiz 'when', because of their semantic similarity with conditional protases. According to the authors, four sub-cases must be distinguised: noiz can either be used alone, or followed by eta, or followed by ere, or by eta ere. Likewise, baldin can be used on its own, or followed by eta, or yet by a longer form, -eta-ria $(k)$.

Interestingly, Leiçarraga's (1571) NT contains many cases of baldin-eta, but none of noiz-eta; the same is true of Etcheverry of Ciboure (1636), and, to a lesser degree, of Etcheverry of Sare (1712), who uses, however, noiz-eta-ere. Likewise, Haraneder (1740, 1750 ) uses baldin.eta.ria $(k)^{32}$ in conditional clauses, but never noiz-eta without ere following. But the reverse situation is also attested: Axular (1643) and Laphitz (1867) never use baldin-eta(-ria(k)), but they do use noiz-eta (without ere) quite systematically. Axular does not have a single instance of either noiz-ere or of noiz-eta-ere, whereas Laphitz does not used noiz-ere but has one occurrence of noiz-eta-ere.

\section{Conclusions}

The main issue raised in this paper was whether Basque complex correlative sentences constitute a special type of sentences, or whether it is possible to reduce them to other, existing constructions. To this effect correlative protases have been compared with various other clauses: semi-free relatives, dependent clauses containing an explicit whword (appositive relatives, indefinite free relatives, embedded questions and unconditionals), and conditional protases. The results of the comparison were summarized in Table 1 in Section 4.4 and the special section on conditionals in 5. Here we recapitulate the most important findings.

i. Concerning the link between semi free relatives (SFRs) and CorPs, we have shown that they arguably have different syntactic structures. While SFRs are nominal in nature (DPs), CorPs are clausal (CPs). The two are also different from each other in the way they are connected with the main clause. While both types of relative clauses can appear in the left periphery and may be resumed by a pronominal correlate, the two clauses differ in the presence of the linker eta, which can only accommpany CorPs in complex correlative sentences. Although we have left their semantic analysis completely in the vague so far, it is worth noticing that just like SFRs, CorPs seem to be neutral with respect to the three basic types $e,\langle e, t\rangle$ and $<<e, t>, t>$ they represent. They sometimes yield entities, as in (50), sometimes properties, as in (36) and (37), and sometimes generalised quantifiers, when the whole CCS predicates something of the elements of a closed set. It is therefore 
tempting to suggest that CorPs compositionally provide a property (the movement of the wh-word creating a gap, and the wh-word itself transmitting a $\lambda$ feature to the $\mathrm{C}^{\circ}$ it specifies): ${ }^{33}$ the type shifts identified by Partee (1987) would then allow a reinterpretation triggered by contextual and pragmatics factors (and the possible "widening effect" of ere, to borrow Dayal's (1997) expression).

ii. Concerning the link between correlatives and dependent wh-clauses, we can say that unconditional or "no matter clauses" are the type that most closely approximates CorPs. In particular, ere is much preferred today in CorPs, and unconditionals are the only other type of wh-clauses which also allows its presence. This corroborates the idea that the basic contribution of ere is to express that there is no other property than those specified in the clause that is relevant (as in the case of CCSs) or irrelevant (as in the case of unconditionals) to the rest of the complex sentence, i.e. to the content of the apodosis.

iii. Finally, we have compared CSSs to conditional sentences whose apodoses contain an indefinite pronoun or a negative polarity item. ${ }^{34}$ As an anonymous reviewer remarked after reading the first version of this paper, which was much more sympathetic to Lafon's theory than the present version, what the diachronic data really show is that there has clearly been a convergence in the means of expressing CCSs and conditional sentences, probably because of their semantic closeness.

Given the above results, we hope to have contributed to a better understanding of complex correlative sentences. Next to asking whether CCSs constitute a special type of sentences, the final answer to which must unfortunately await further research, we have also touched upon questions of structural properties and syntactic composition. We have entertained the view that CorP's position in the main clause might follow from properties of the linker eta. This element seems to select a wh-free relative clause in its specifier, and of a FocusP à la Rizzi as its complement. If this is indeed the case, the fact that a CorP must by definition have a pronominal correlate (hosted by SpecFocusP), whereas unconditional clauses need not have one, would be quite natural. It needs to be seen if correlatives in every language are amenable to an analysis along this line. Hopefully, a careful examination of CCSs across many languages will sooner or later provide a possible clue to this question.

\section{Acknowledgements}

First and foremost, I must thank Anikó Lipták, not only for having asked me to write this paper, but also for her keen interest in Basque syntax and for her precious remarks on two preliminary versions of this paper. I am grateful to Aurelia Arkotxa, Esther Mortalena, Beñat Oyharçabal and Marie Pourquié for discussions concerning both the acceptability of older (attested) examples and the grammaticality of those that pertain to the contemporary language. I also wish to thank two anonymous reviewers, who pointed out many shortcomings in the first version of this paper, and forced me to revise some of my analyses. Needless to say, all remaining errors are 
mine only. This paper is an outgrowth of the collective work undertaken between 2003 and 2005 in the research group "Structure de la phrase / La périphérie gauche" funded by CNRS (Fédération Typologie et universaux linguistiques).

\section{References}

(A) Basque sources ${ }^{35}$

[AnBa 1828] Anonymous, 1828. Jesus-Christo gure Jaunaren laur Ebanyelioac [...]. Bayonne: Lamaignière, 1828.

Arambillaga, d' A. 1684. Jesu Christoren Imitacionea [books III and IV]. Bayonne: Fauvet.* Astarloa, Pedro. 1816-18. Urteco Domeca gustijetaraco verbaldi icasibidecuac [...]. [Cited in Arejita (1978)].

Axular, Pedro. 1643. Gero. Bordeaux: Milanges. Facsim.: Bilbao: Euskaltzaindia, 1988. Edition with modernized spelling by Luis Villasante, Barcelona: Juan Flors, 1964.

Baratciart, André. 1787. Guiristinoqui bicitceco eta hiltceco moldea. Bayonne: Fauvet-Duharte.*

Cazenave [Casenave], A. c. 1860. Jesu Khristoin Ebanjelio Seindia San Mathiuïn aäbera. Manuscript. In Rosa Miren Pagola et al (eds), Bonaparteko Ondareko Eskuizkribuak, Ekialdeko behe-nafarrera, I, 17-76. Bilbao, Deustuko Unibertsitatea, 1999.

Chourio, Michel de. 1720. Jesu-Christoren Imitacionea [ ] Escararat itçulia. Reprint, Bayonne: Trebos, 1788; facsim. of the latter, San Sebastián: Hordago-Lur, 1979.*

Duhalde, Martin. 1809. Meditacioneac [...].Facsim., San-Sebastián: Hordago-Lur, 1978.*

Duvoisin, Jean-Pierre. 1859-65. Bible edo Testament Zahar eta Berria [...]. London. Facsim., Bilbao: Gran Enciclopedia Vasca, 1972.

"EAB" [anonymous collective work]. 1994. Elizen arteko Biblia. Lazkao: Sociedades Bíblicas Unidas \& Bilbao: Bibli Elkarte Batuak \& Euskal Eizbarrutiak.

Echenique, Bruno. 1857. El Evangelio segun San Mateo [...]. London. Facsim. in Louis-Lucien Bonaparte, Opera Omnia Vasconice, II, 91-151. Bilbao: Euskaltzaindia, 1991.

"EHEG" [anonymous collective work], 1980. Itun Berria. San-Sebastián: Idatz (Herriko Elizbarrutietako Gotzaiak).

Etchehandy, Marcel. 1999. Testamendu Berria. Belloc: Biblia Elkartea \& Madrid: Sociedades Bíblicas Unidas.

Etchepare, Bernat. 1545. Linguae vasconum primitiae. Edited by P. Altuna, Bilbao: Mensajero, 1980.*

Etcheverry of Ciboure, Joanes [Etxeberri Ziburukoa]. 1636. Elizara erabiltzeko liburua. New printing, Bordeaux: Mongiron Milanges, $1665 .^{*}$

Etcheverry of Sare, Joanes [Etxeberri Sarakoa, J.]. 1712. Obras vascongadas. Ed. by Julio de Urquijo é Ibarra, Paris: Geuthner, 1907.*

"Ezkila" [anonymous collective work], 1974. Jesu Kristoren Berri Ona. Bonloc (Pyrénées-Atlantiques): Editions Ezkila.

Haraneder, Joanes. 1740. Jesu Christoren Evangelio Saindua. Edited by P. Altuna, Bilbao: Euskaltzaindia, $1990 .^{*}$

Haraneder, Joanes. 1750. Gudu izpirituala. New edition. Bayonne: Cluzeau, 1827.*

Haristoy, Pierre. 1896. Jesu-Kristoren Imitazionea. Pau: Sylvain Dufau \& Vugnancour.

Harriet, Maurice. 1855. Iesu-Christo gure Iaunaren Testament Berria [...]. Bayonne: Lasserre.

Hiriart-Urruty, Jean. 1891. Biba eskuara, in Eskualduna (13/11). Reprinted in Inaki Camino (ed.), Gontzetarik jalgiaraziak. Bilbao \& San Sebastián: Euskal Editoreen Elkartea, 1995.* 
Hiriart-Urruty, Jean. 1893. Gure indarrak. In Eskualduna (06/10). Reprinted in Pierre Lafitte (ed.), Mintzaira, Aurpegia, Gizon. Oñate: Editorial Franciscana Aránzazu, 1971.*

Inchauspé, Emmanuel. 1856. Jesus-Kristen Ebanjelio Saintia Sen Mathiuren arauéra. Bayonne: Lamaignère. Facsim. In Louis-Lucien Bonaparte (1991) Opera Omnia Vasconice, II. 167243. Bilbao: Euskaltzaindia.

Inchauspé, Emmanuel. 1883. Jesu-Kristen Imitacionia. Bayonne: Lamaignère.

Iribarnegaray, Vicaire -. c. 1860. Yesu Chrichtoin Ebanyeliua San Mathioin arabera. Manuscript. Published in Rosa Miren Pagola et al (eds), Bonaparte Ondarreko Eskuizkribuak, Mendebaldeko behe-nafarrera. 19-81. Bilbao: Deustuko Unibertsitatea, 1999.

Kerexeta, Jaime. 1976. Euskal-Biblia (bizkaieraz). Bilbao: Bilbo'ko Elizbarrutiko Gotzaintza.

Lapeyre, Etienne. 1891. Credo edo sinhesten dut esplikatua. Edited by Luis Villasante. Bilbao: Euskaltzaindia, 1982.*

Laphitz, Franzisko. 1867. Bi saindu hescualdunen bizia [...]. Facsim., San-Sebastián: Hordago/ Lur, 1978.*

Léon, Léon. 1929. Jesu-Kristoren Imitazionea. Turnhout, Belgium: Brepols. ${ }^{*}$

Léon, Léon. 1946. Jesu-Kristo gure Jaunaren Ebanjelio Saindua. Ustaritz: published by the author.

Leiçarraga, Johannes. 1571. Iesus Christ Gure Iaunaren Testamentu Berria - Kalendera - ABC edo Christinoen Instructionea. La Rochelle. Reprinted in facsim. as: I. Leiçarragas Baskische Bücher von 1571, by Theodor Linschmann and Hugo Schuchardt, Strasburg, 1900.*

Maister, Martin. 1757. Jesu-Kristen Imitacionia. Pau: Dugué \& Desbaratz.

Pouvreau, Silvain. 1669. Iesusen Imitacionea. Edited with modernised spelling by José María Satrústegui, San-Sebastián: Hordago/Lur, 1979.*

Salaberry d'Ibarolle, M., 1856. L'Evangile selon Saint Mathieu [...]. Facsim. in Louis-Lucien Bonaparte, Opera Omnia Vasconice, III, 335-420. Bilbao: Euskaltzaindia, 1991.

Soubelet, Domingo. 1969. Jesus. Ligugé (Vienne, France): Presses d’Aubin.

Ubillos, Juan Antonio. 1785. Christau doctriñ berri-ecarlea [ ].Facsim. with an Introduction by Patxi Altuna. Bilbao: Euskaltzaindia, 1989.

Zavala, Antonio. 1985. Esaera Zaararen bilduma berria I, II. Tolosa: Auspoa, \#184 and \#185.

Sources of the Latin texts and their translations.

The Bible. Latin Vulgate. Downloadable at: http://www.thelatinlibrary.com/bible.html

The Bible. King James' Version.

Thomas à Kempis. \pm 1425 . De imitatione Christi. Downloadable at: http://www.thelatinlibrary. com/kempis.html

English Translation: Benham, W., 1905. Imitation of Christ. London: Routledge \& New York: E.P. Dutton.

(B) Linguistics

Agud, Manuel \& Antonio Tovar. 1989. Materiales para un diccionario etimológico de la lengua vasca (V). Anuario del Seminario de Filología Vasca "Julio de Urquijo", 23 (2). 463-532.

Arejita, Adolfo. 1978. Euskal Joskera [Basque syntax]. Durango: Zugaza.

Artiagoitia, Xabier. 2002. The functional structure of the Basque noun phrase. In Xabier Artiagoitia et al. (eds), Erramu Boneta: Festschrift for Rudolf P. G. de Rijk, 73-90. San-Sebastián / Donostia \& Vitoria / Gasteiz: Diputación Foral de Gipuzkoa and Universidad del País Vasco, Supplements of ASJU 44.

Bhatt, Rajesh. 2003. Locality in Correlatives. Natural Language and Linguistic Theory 21(3). $485-541$. 
Bittner, Maria. 2001. Topical referents for individuals and possibilities. In Rachel Hastings, Brendan Jackson \& Zsófia Zvolenszky (eds.), Proceedings of SALT XI, 36-55. CLC, Ithaca.

Boškovič, Zeljko. 1997. Superiority effects with multiple wh-fronting in Serbo-Croatian. Lingua 102. 1-20.

Cable, Seth. 2005. The syntax and semantics of the Tibetan correlative. Manuscript. Downloadable at: http://web.mit.edu/scable/www/work/papers/Tibetan-Correlative-SynSem.pdf (1 June 2006)

Cable, Seth. This volume. The syntax of the Tibetan correlative.

Caponigro, Ivano. 2001. On the semantics of indefinite free relatives. In Marjo van Koppen, Joanna Sio \& Mark de Vos (eds), Proceedings of ConSOLE X, 49-62. Leiden: SOLE.

Caponigro, Ivano. 2004. On the source of maximality in wh-constructions crosslinguistically. In Mary Andronis, Erin Debenport, Anne Pycha \& Keiko Yoshimura (eds), Chicago Linguistics Society, 38 (1). 125-144.

Chomsky, Noam. 1956. Three models for the description of language. I.R.E. Transactions of Information Theory 2. 133-124.

Citko, Barbara. This volume. What don't wh-questions, free relatives, and correlatives have in common?

Dayal, Veneeta. 1996. Locality in wh-quantification: Questions and relative clauses in Hindi. Studies in Linguistics and Philosophy 62. Dordrecht: Kluwer Academic Publishers.

Dayal, Veneeta. 1997. Free relatives and ever: identity and free choice readings. In Aaron Lawson (ed.), Proceedings of SALT VII, 99-116. Ithaca, NY: CLC Publications.

É. Kiss, Katalin. 1995. NP Movement, Operator Movement, and Scrambling in Hungarian. In Katalin É. Kiss (ed.), Discourse Configurational Languages, 207-243. Oxford: Oxford University Press.

Etxepare, Ricardo. 2003. Exclamatives. In José I. Hualde \& Jon Ortiz de Urbina (eds), A Grammar of Basque, 564-572. Berlin: Mouton de Gruyter

Greenbaum, Sidney. 1969. Studies in English adverbial usage. London: Longman.

Grosu, Alexander. 2004. The syntax-semantics of modal existential wh constructions. In Olga Tomic (ed.), Balkan Syntax and Semantics, 405-438. Amsterdam/Philadelphia: John Benjamins.

Haudry, Jean. 1973. Parataxe, hypotaxe et corrélation dans la phrase latine. Bulletin de la Société Linguistique de Paris 68. 147-186.

Ithurry, Abbé. 1895. Grammaire basque. Dialecte labourdin. Bayonne: New Printing (Facsim. 1979, San Sebastian: Hordago).

Izvorski, Roumyana. 1996. The syntax and semantics of correlative proforms. In Kiyomi Kusumoto (ed.), Proceedings of NELS 26, 133-147. Amherst, MA: GLSA.

Izvorski, Roumyana. 2000. Free adjunct free relatives. In: Roger Billerey \& Brook D. Lillehaugen (eds), WCCFL Proceedings, 232-245. Somerville, MA: Cascadilla Press.

Lafon, René. 1944. Le système du verbe basque au XVIe siècle, I, II. Bordeaux: Delmas and Université de Bordeaux. Facsim., San Sebastián: Elkar, 1980.

Lafon, René. 1966. La particule BAIT en basque: ses emplois morphologiques et syntaxiques. Bulletin de la Société de linguistique 61.1. Reprinted in Jean Haritschelhar and Zabaltzagarai Charritton (eds), 1999. Vasconiana. 667-693. Bilbao: Euskaltzaindia.

Levin, Beth. 1983. Ergativity. Doctoral dissertation, MIT.

Lipták, Anikó. 2000. Multiple relatives as relatives of questions. In Gábor Alberti \& István Kenesei (eds), Approaches to Hungarian, VII: Papers from the Pécs Conference, 153-177. Szeged: JATE Press. 
Lipták, Anikó. 2005. On the correlative nature of Hungarian left peripheral relatives. In Benjamins Shaer, Werner Frey \& Claudia Maienborn (eds), Proceedings of the Dislocated Elements Workshop, ZAS Papers in Linguistics, 35:1. 287-313. Berlin, ZAS.

Oyharçabal, Bernard. 1987. Etude descriptive de constructions complexes en basque. Paris: Université de Paris VII dissertation [Thèse d'Etat].

Oyharçabal, Bernard. 2003. Relatives. In José.I. Hualde \& Jon Ortiz de Urbina (eds), A grammar of Basque, 762-823. Berlin: Mouton de Gruyter.

Partee, Barbara. 1987. Noun phrase interpretation and type-shifting principles. In Jeroen Groenendijk, Dick de Jong \& Martin Stokhof (eds), Studies in discourse representation theory and the theory of generalized quantifiers, 115-143. Dordrecht: Foris.

Quirk, Randolph, Sidney Greenbaum, Geoffrey Leech \& Jan Svartvik. 1972. A Grammar of contemporary English. London: Longman.

Rebuschi, Georges. 1998. Nouvelles remarques sur 'haina'. Lapurdum 3. 53-75. [Bayonne, France.]

Rebuschi, Georges. 2000. A propos d'une construction non-standard du basque. Lapurdum 5. 237-282. [Bayonne, France].

Rebuschi, Georges. 2001. Note sur les phrases complexes à protase corrélative du basque. Lapurdum 6. 261-289. [Bayonne, France].

Rebuschi, Georges. 2005. Generalizing the antisymmetric analysis of coordination to nominal modification. Lingua 115 (4). 445-459.

Rebuschi, Georges. 2006. A new look at Northern Basque wh-free relative clauses'. In Beatriz Fernández \& Itziar Laka (eds), Andolin gogoan; Essays in Honour of Professor Eguzkitza, 779-798. Vitoria, Spain: Servicio Editorial de la Universidad del País Vasco.

Rebuschi, Georges and Anikó Lipták. To appear. Northern Basque free relatives and the left periphery. In Hans G. Obenauer (ed.), Studies on the left periphery [provisional title].

Rizzi, Luigi. 1997. The fine structure of the left periphery. In Liliane Haegeman (ed.), Elements of grammar. Handbook of generative syntax, 281-337. Dordrecht: Kluwer.

Rotaetxe Amusategi, Karmele. 2004. (E)ta enklitikoa sailkapen eskalarrean [=A scalar analysis of the enclitic (e)ta, in Basque]. Fontes Lingvee Vasconum 95. 115-139 [Pamplona, Spain].

Srivastav, Veneeta. 1991. The Syntax and Semantics of Correlatives. Natural Language and Linguistic Theory 9 (4). 637-686.

Tiffou, Etienne \& Richard R. Patry. 1995. La relative en bourouchaski du Yasin. Bulletin de la Société de Linguistique 90 (1). 335-390.

Trask, Robert L. 1997. The history of Basque. London: Routledge.

Tredinnick Victoria. 2003. Modal Flavor and Quantificational Force in Free Relatives with ever. NELS 34 poster session, available at: http://www.ic.sunysb.edu/clubs/nels/abstracts/tredinnick.pdf. (17 December 2008)

Zaefferer, Dietmar. 1990. Conditionals and Unconditionals in Universal Grammar and Situation Semantics. In Robin Cooper et al. (eds), Situation Theory and its Applications I, 471492. Stanford, CA: CSLI.

Zaefferer, Dietmar. 1991. Conditionals and Unconditionals: Cross-linguistic and Logical Aspects. In Dietmar Zaefferer, (ed.), Semantic universals and universal semantics, 210-236. Dordrecht: Foris.

Zribi-Hertz, Anne \& Jean-François Hanne. 1995. Pronoms, déterminants et relatives en bambara de Bamako. Linguistique africaine 15. 91-135.

Zuazo, Koldo. 1998. Euskalkiak, gaur. [The Basque dialects, today]. Fontes Lingvee Vasconum 78, 191-233. [Pamplona, Spain]. 


\section{Endnotes}

1. Chomsky (1956) mentions similar sentences, namely "If $S_{1}$, then $S_{2}$ " and "Either $S_{3}$, or $S_{4}$ " as examples of "dependencies" that Markovian chains cannot account for, but, as far I am aware, he never dealt with them or their like in any of his transformational models.

2. The abbreviations used in the glosses are the following: ABL, ablative; ABS, absolutive; ACC, accusative; ADN, adnominalizing suffix; ALLOC, allocutive; AUX, auxiliary; $\mathrm{C}^{\circ}$, see COMP; COM, comitative; COMP, complementizer; D, dative; DEM, demonstrative; E, ergative; FACT, factitive; FUT, future; GEN, genitive; HUM, human; IFR, indefinite free relative; IMP, imperative; IMPF, imperfective (also iterative, as far as Basque is concerned); INST, instrumental; LOC, locative; PART, partitive; PRF, perfective; PL, plural; POT, potential; PROS, prospective; PRTC, particle; PST, past; REL: relative marker; SG, singular; SUBJ, subjunctive; UNACC, unaccusative. The symbol ' $\sqrt{ }$ ' indicates that a verb is devoid of any aspectual suffix. The zero or absolutive case suffix is not glossed in the Basque examples. In the glosses of the Basque auxiliaries, the cross reference to the arguments will be represented as follows: 〈A3E1〉: 'absolutive, 3SG-ergative, 1sG〉, 〈A5D6〉: 'absolutive, 2PL-dative, 3PL', etc.; '5' denotes the morphologically plural, but referentially singular, polite 2nd person, and ' 5 " the referentially plural second person. Frequently used abbriviations in the text are: CCS: complex correlative sentence; CorP: correlative protasis $>$; FinP, Finiteness Phrase; FR: free relative clause; FVF: finite verb form; IFR: indefinite free relative. The abbreviations concerning the references are: Imit: Thomas à Kempis' De Imitatione Christi and its various translations into Basque; KJV: the King James' Version of the Bible; LV: Latin Vulgate. Reference to the passages of the Bible will be given according to custom.

3. Not to mention the fact that only a very few pages are devoted to CCSs in Oyharçabal (2003: 818-821).

4. Quite a few counter-examples to that generalisation can be found until well into the 18th century, but not later on, if I am not mistaken.

5. Bait- normally loses its final $-t$ before plosive consonants, but in the frequent $-t+d$ - sequence (where $d$ - encodes A3), the $d$-is generally dropped, except for some authors who drop the $-t$, e.g. baita or baida, bait- $+d a$ 'he/she/it is' $\approx\langle$ A3 3 .

6. Conditional $b a$ - 'if' is unstressed, as in (9a). In (9b), however, the positive assertive particle whose presence is triggered by the FVF being in sentence initial position, is stressed.

7. This is an oversimplification. Although these relatives are typically restrictive, they can also convey an appositive, or non-restrictive, value. See (i) for instance:

(i) Acts 15,8 - LV 'Et qui novit corda Deus testimonium perhibuit...' KJV: 'And God that knows about the hearts, testified about them.'

Bihotz-e-tako berri daki-en Jainkoa-k, lekhukotasun
heart-PL-GEN news knows-en God-E testimony
egi-n izan du.
do-PERF AUX.PERF〈A3E3〉

(Duvoisin 1859-65)

More recent Northern translations, such as "Ezkila" (1974), and even the now received ecumenical translation of the Bible ( $E A B$ 1994), much more typical of the Central and Western dialects, offer the same type of construction for this verse.

8. The ending - ak corresponds both to absolutive plural, and ergative singular; here, it is the former reading that is compatible with the grammatical context, but in (10a,b) or (11a), it is the 
latter. In the word for word glosses, the irregular absolutive plural ending is not segmented: "- $a k$ ", but the regular ergative singular is: "- $a-k$ ". With visible case endings, such as ergative $-k$ or instrumental $-z$, plurality is unambiguously marked by the morpheme $-e-$.

9. Or almost always: none are to be found in Etchepare (1545).

10. Leiçarraga's sources are complex, cf. Lafon (1944, I: 50), but some Greek version was probably used along with a French translation (recall that a Greek text was also the basis of the King James Version).

11. I have added this example, written in euskara batua or "unified Basque", a standardised written language which borrows much more from the Southern (Central and Western) dialects than from the Eastern ones, among which those spoken in France. This is because I intend to show that the construction and its interpretation have remained stable during the whole history of the language, and therefore cannot be regarded as marginal.

12. The cases illustrated (21a-c) is obviously more complex. One possible account is to consider that the first case-marked conjunct refers to a maximal individual, and that eta materializes the connective that is usually, but not always, left phonetically unrealised cross-liguistically when a restrictive relative modifies its antecedent (see Rebuschi 2005 for independent arguments and evidence).

13. Note that the restrictive relative clause within this DP follows, rather than precedes, the head-noun gizon 'man'. It is not an appositive relative, since gizon is not marked for number. See also (48a) infra. On the (non-un)grammaticality of this word-order, see Oyharçabal (1987).

14. Iraun 'to last, persist' is a so-called "unergative" verb; as a consequence, its unique argument is in the ergative case (see Levin 1983 on this).

15. The last clause in (32b) also contains a zero resumptive or correlative demonstrative (a little pro). Let us add that the case clash in the second conjunct of (29a) between the wh- item nor-i (which is in the dative because it is the indirect object of the verb manifestatu 'impart') and the case required for the subject of the main clause predicate 'know the Father' is only licit - at least today -, precisely because it is a second conjunct: otherwise, such structures have been only possible since the 18th century if the same morphological case is assigned both by the main clause verb, and by the embedded verb too. A detailed analysis of this evolution must be left for future research.

16. There is no distinction between the absolutive and ergative cases for this plural pronoun, 'ye-all'.

17. A finite verb is [allocutive] if it incorporates a morpheme indicating familiarity (as here) or, in fewer dialects, respect, with respect to the hearer, without the latter being represented by an argument of the verb.

18. The periphrastic subjunctive mood is built with a second series of auxiliaries, e.g. with the root -eza- rather than - $u$ - for 'have' with transitive verbs, and the root of (or perhaps a zero aspectual suffix on) the lexical verb. As for the Basque periphrastic "future", it is built by the combination of the prospective aspectual ending on the lexical verb, the inflected auxiliary in the present tense.

19. Interestingly, in older Biscayan, CCSs existed, and could be in the subjunctive, as shown in (i) (in Southern Basque, what are verbal roots in Northern Basque also carry the -PERF suffix, but the root of the auxiliary is different from the one used in the indicative mood). 
(i) In 20,23 LV: 'Quorum remiseritis peccata, remissa sunt eis; quorum retinueritis, retenta sunt.' / KJV: 'Whose soever sins ye remit, they are remitted unto them; and whose soever sins ye retain, they are retained.'

Nor-tzu-ben pekatu-bak parkatu daikezubeza- $n$, who-PL-GEN Sin-PL forgive 〈A6E5'[SUBJ]〉-en parka-tuko jakez, eta nor-tzu-ben-ak geratu forgive-PROS 〈A6D6〉 and who-PL-GEN-PL leave daikezubeza- $n$ geratuak izango dira. $\langle\mathrm{A} 6 \mathrm{E} 5$ '[SUBJ] $>$-en leave.PERF.PL AUX.PROS $〈 \mathrm{~A} 6$ 〉

(Astarloa 1816-18, cited in Arejita 1978: 135)

Moreover, the subjunctive mood can also be used in SFRs which have a generic of universal value, in certain varieties of Bizcayan Basque again. A 20th translation of the Bible into this dialect thus reads for the same passage:

(ii) Zuek pekatu-ak parkatu dagiezuez-an-a-i you-PL sin-PL forgive 〈A6D6E5'[suBJ]〉-en-PL-D parka-tu-ta gera-tuko yakez; zu-ek pekatu-ak forgive-PERF-ta stay-PROSP 〈A6D6〉 you-PL sin-PL lotu dagiezuez-an-a-i lo-tu-ta retain $\langle\mathrm{A} 6 \mathrm{D} 6 \mathrm{E} 5$ ' $[\mathrm{SUBJ}]>-\mathrm{en}-\mathrm{PL}-\mathrm{D}$ retain-PERF-ta geratuko yakez- (Kerexeta 1976) stay-PROS 〈A6D6〉

Lit., '[Those to whom you will forgive $\left.[\text { the sins }]_{i}\right]_{j}$, they ${ }_{i}$ will remain-to-them ${ }_{j}$ forgiven; [those to whom you will retain $\left.[\text { the } \operatorname{sins}]_{i}\right]_{j}$, they ${ }_{i}$ will remain-to-them ${ }_{j}$ retained.'

20. Likewise, for Mt 5,31-32, the KJV has whosoever three times, Leiçarraga (1571) and Léon (1946) have three correlatives (in nork ere bait-), and "Ezkila" (1974) and Etchehandy (1999) have three SFRs - but Duvoisin (1859-65) has two unconditionals and one SFR, whereas the Latin Vulgate respectively displays quicumque, omnis qui, and qui in that order.

21. Zein can also function as a wh- determiner or modifier, as in zein gizon? 'which man/men?' in interrogatives, or zein gizon ere 'whichever man' in CorPs, in whichcase no number affix can

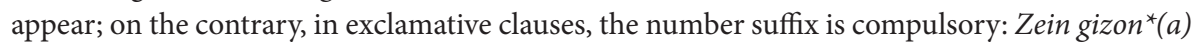
(den)! 'What a man (he is)!'

22. Example (56) also shows that the default singular agreement in the FVF of the CorP was not the only option at that time (but it is nowdays), since it displays a plural morpheme for the argument in the absolutive case. Nowadays, a plural correlate is still possible in the apodosis, but within the protasis>, the only possible agreement-marking in the FVF is the default value, the singular.

23. There is no known etymology for balin and baldin, and only the latter is mentioned (as a mere variant of ba-) in Agud and Tovar (1989: 531).

24. The situation was more confusing until the end of the 17th century. For instance, Axular (1643) did not distinguish between balin and baldin, but the description in the text is correct as far as later stages of the language are concerned - contra the description provided in Hualde \& de Urbina eds. (2003: 724-726), which only reflects Southern Basque grammar.

25. The Basque texts are either translations of the NT itself, or of the same verse as quoted in Thomas' Imitation, the original version of which contains the very words of the Latin Vulgate. 
26. The relevant FVFs are characterized by a prefix $l$ - rather than $d$-in the present tense, and $z$-in the past tense, when the argument or all the arguments are 3rd person(s). But if there is a 1st or 2nd person prefix, it is identical with the one used in the past tense, the difference lying in the fact that the irrealis FVF is not followed by the past tense marker $-(e) n$.

27. The author, and the dialect of his book, are Guipuzcoan, i.e. Central, not Eastern, Basque, but this sentence is clearly borrowed from a neighbouring dialect: P. Altuna, in his introduction to the facsimile republication of the book in 1989, explicitly wonders whether the sentence is really Guipuzcoan, i.e. Central, Basque - and it is obviously not.

28. On the one hand, diphthongs devoice a following voiced plosive at morpheme boundaries, as in N.B. $z a i-k u$ ou $z a u-k u$ for /zai-gu/'it is to us' $\langle\mathrm{A} 3 \mathrm{D} 4$, , and transform fricatives into affricates, as in N.B. $d(e r) a u-t z u$ for /d(er)au-zu/ 's/he-has-it-to-you', cf. standardised and Guipuzcoan Basque $d i-z u$, id. On the other hand, a - $t$ - often appears for instance in compounds such as sutondo 'fireplace', from su 'fire' and ondo 'side'. Whence for instance, on the one hand, baikara for bai(t)-gara 'bait-we-are', and, on the other hand, baitaiz for bai-(h)aiz 'bait-thou art' (as in (46) in 4.2).

29. The symbol " $\diamond$ " indicates an obviously unattested, but reconstructed, (word or sentence) form, to be distinguished from the use of '*) as marking ungrammatical ones.

30. Nehor and its variant nihor most likely result from the prefixation of the negative morpheme $e z$, whose consonant traditionally fell before nasal consonants, as is attested by the traditional spelling enaiz of ez naiz 'I am not', to be contrasted with ezta 's/he is not' (today's normalised as $e z d a$ ), ezkara 'we are not' (spelled ez gara today), and so forth.

31. The position of the negative morpheme $e z$ to the left of balin indicates that balin plus $b a$-are one syntactic word - as opposed to baldin... $b a-$, since in this case $e z$ must immediately precede $b a-$. A clear illustration is provided by Larreguy (1775, chap. 31):

(a) Othoitz-tu zuen Laban ez gaitzezte-az

pray-PERF 〈A3E3[PAST] $>$ Laban NEG getting.angry-INST

baldin ez balin ba-zen altxa-tzen hari

baldin NEG balin if- «A3[PAST]> get.up-IMPF DEM-D

agur egiteko.

hail to.do

'She prayed Laban not to be angry if she did not stand up to greet him.'

32. There is no known account of the third morph, -ria $(k)$ in this form.

33. See Caponigro (2004) for a variant, according to which the translation of the wh-words is: $\lambda \mathrm{X} \lambda \mathrm{x}[\mathrm{P}(\mathrm{x}) \wedge \mathrm{X}(\mathrm{x})]$, where the property variable $\mathrm{P}$ ranges over animates, inanimates, location, manner, according tho the specific morpheme associated with the wh- "prefix" (who, what, where, how... respectively).

34. Interestingly, the presence of a pronominal correlate is not necessary either, cf. If anybody enters the room, tell him/her/them to go away, but also If anybody enters the room, pretend you're asleep. However, the relevance of the content of the protasis $>$ is indisputable in both cases.

35. The references followed by a star $\left.{ }^{*}\right)$ are freely downloadable at: http://klasikoak.armiarma. com/alfa.htm. 